\title{
MAGNITUDE AND FREQUENCY OF FLOODS IN SMALL DRAINAGE BASINS IN IDAHO
}

\section{U.S. GEOLOGICAL SURVEY}

Water-Resources Investigations 7-73

Prepared in cooperation with the Idaho Department of Highways, the Idaho Department of Water Administration, and the U.S. Forest Service 


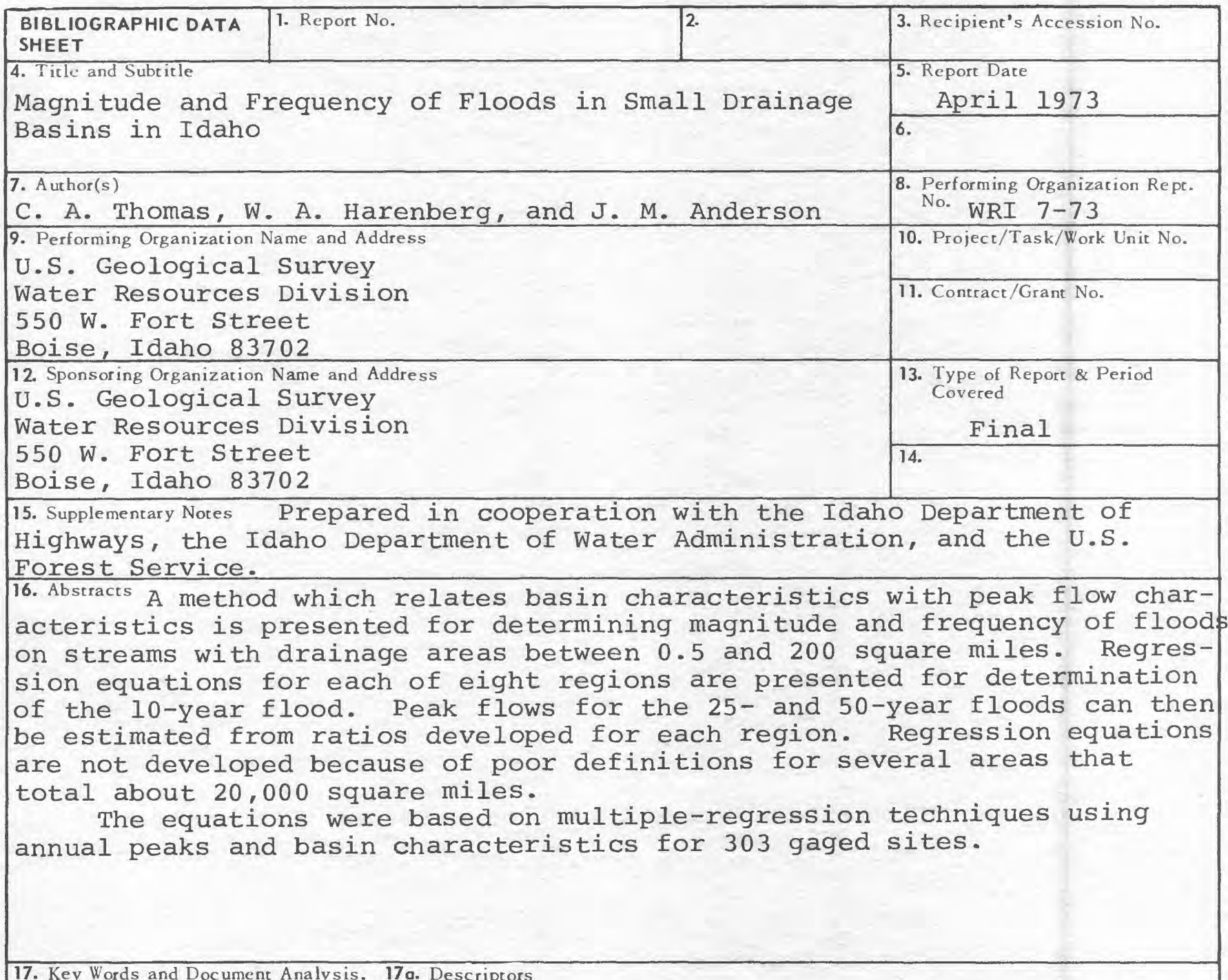

Design flood, *Regional flood, Annual peak discharge, Floods, *Flood frequency, Flood recurrence interval, *Frequency analysis, Frequency curves, Statistical methods, *Small watersheds, Regional analysis, Regression analysis, *Idaho, Crest-stage gage, Gaging stations

17b. Identifiers/Open-Ended Terms

Flood magnitude

17c. COSATI Field/Group

18. Availability Statement No restriction on distribution. Available from National Technical Information Service, Springfield, Va. 22151

\begin{tabular}{|l|l|}
\hline $\begin{array}{l}\text { 19. Security Class (This } \\
\text { Report) } \\
\text { UNCLASSIFIED }\end{array}$ & $\begin{array}{c}\text { 21. No. of Pages } \\
53\end{array}$ \\
\hline $\begin{array}{l}\text { 20. Security Class (This } \\
\text { Page } \\
\text { UNCLASSIFIED }\end{array}$ & 22. Price \\
\hline
\end{tabular}




\section{MAGNITUDE AND FREQUENCY OF FLOODS IN SMALL DRAINAGE BASINS IN IDAHO}

By C. A. Thomas, W. A. Harenberg, and J.M. Anderson

\section{U.S. GEOLOGICAL SURVEY}

Water-Resources Investigations 7-73

Prepared in cooperation with the Idaho Department of Highways, the Idaho Department of Water Administration, and the U.S. Forest Service

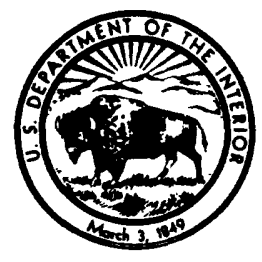




\section{UNITED STATES DEPARTMENT OF THE INTERIOR \\ Rogers C. B. Morton, Secretary GEOLOGICAL SURVEY \\ Vincent E. McKelvey, Director}

For additional information write to:

U.S. Geological Survey

P.O. Box 036, Federal Building

550 West Fort Street

Boise, Idaho 83702 


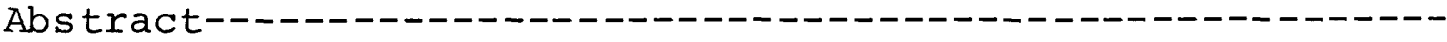

Introduction----------

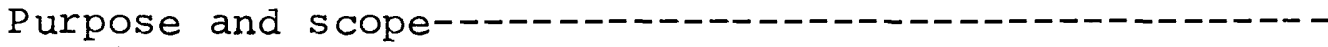

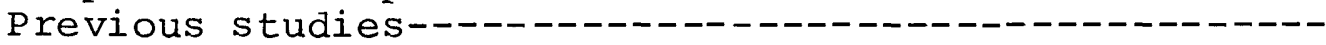

Design method-----------------------------------------

Basin characteristics-----------

Relative magnitude of floods----------------------

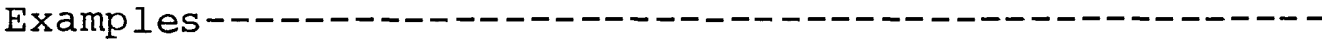

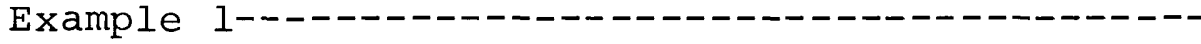

Example 2----------

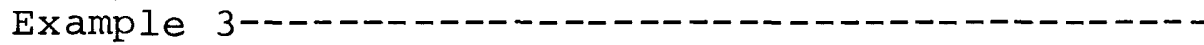

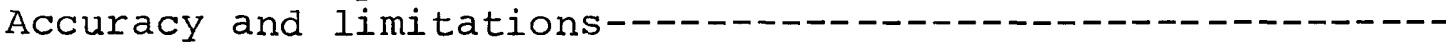

Undefined areas where regression relations do not apply---

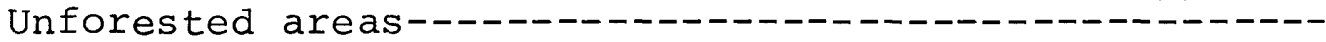

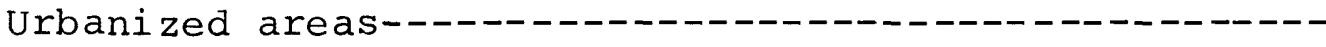

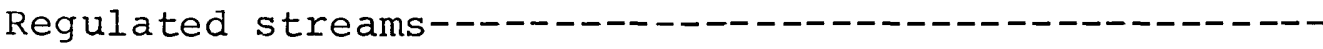

Streams with losing or gaining reaches--------------

Alluvial valleys and the Snake Plain----------------

Intense thunderstorm-prone areas------------------

Anomalous areas----------------------------------

Analytical techniques---------------------------------

Magnitude and frequency of floods at gaged sites-----

Multiple regression model-------------------------

Investigation of other characteristics-----------

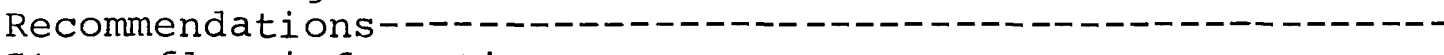

Streamflow information------

Sources of information---n-----

Gaging-station-numbering system------------------

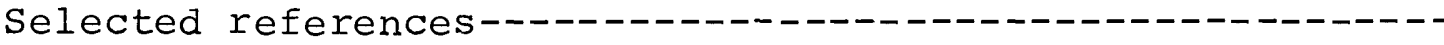

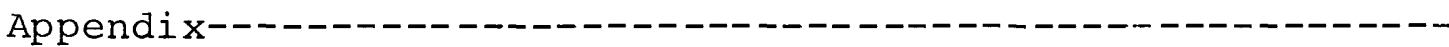

Glossary---------------------------------------

Other basin characteristics investigated in the

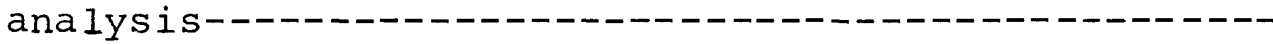

Page 


\section{ILLUSTRATIONS}

Figure 1. Map of Idaho showing locations of gaging stations

Page used in the analyses, regions and some areas and streams for which regression equations do not apply------------------------------In pocket

2. Map of Idaho showing basin boundaries and maximum known unit discharges at miscellaneous

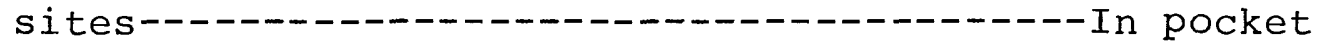

3. Graph of maximum discharges in relation to drainage area--

\section{APPENDIX}

\section{ILLUSTRATIONS}

Figure A-1. Nomograph for computing floods in Region 1----

A-2. Nomograph for computing floods in Region 2----

A-3. Nomograph for computing floods in Region 3----

Page

A-4. Nomograph for computing floods in Region 4----

A-5. Nomograph for computing

floods in Region 5----

A-6. Nomograph for computing

computing

floods

in Region 6----

$A-7$. Nomograph for

computing

floods in Region 7----

\section{TABLES}

Table A-1. Summary of regression equations for peak dis-

Page charges for the eight regions-_-_-n 36

A-2. Drainage areas, flood discharges at selected frequencies, and maximum flows of record for small streams with 8 years or more of recordA-3. Maximum discharges at selected sites--.---.--A-4. Gaging stations at which the Q10 determined by the modified log-Pearson method differs by more than 70 percent from the $Q_{10}$ determined by the regional equation--..-- 


\section{MAGNITUDE AND FREQUENCY OF FLOODS IN}

SMALL DRAINAGE BASINS IN IDAHO

By C. A. Thomas, W. A. Harenberg, and J. M. Anderson

ABSTRACT

A method is presented in this report for determining magnitude and frequency of floods on streams with drainage areas between 0.5 and 200 square miles. The method relates basin characteristics, including drainage area, percentage of forest cover, percentage of water area, latitude, and longitude, with peak flow characteristics.

Regression equations for each of eight regions are presented for determination of Q10, the peak discharge, which, on the average, will be exceeded once in 10 years. Peak flows, 225 and $Q_{50}$, can then be estimated from $Q_{25} / Q_{10}$ and $Q_{50 / Q_{10}}$ ratios developed for each region. Nomographs are included which solve the equations for basins between 1 and 50 square miles.

The regional regression equations were developed using multiple regression techniques. Annual peaks for 303 sites were analyzed in the study. These included all records on unregulated streams with drainage areas less than about 500 square miles with 10 years or more of record or which could readily be extended to 10 years on the basis of nearby streams. The log-Pearson Type III method as modified and a digital computer were employed to estimate magnitude and frequency of floods for each of the 303 gaged sites. A large number of physical and climatic basin characteristics were determined for each of the gaged sites. The multiple regression method was then applied to determine the equations relating the floodflows and the most significant basin characteristics. For convenience of the users, several equations were simplified and some complex characteristics were deleted at the sacrifice of some increase in the standard error. Standard errors of estimate and many other statistical data were computed in the analysis process and are available in the Boise district office files. The analysis showed that Q10 was the best defined and most practical index flood for determination of the $Q 25$ and $Q_{50}$ flood estimates. 
Regression equations are not developed because of poor definition for areas which total about 20,000 square miles, most of which are in southern Idaho. These areas are described in the report to prevent use of regression equations where they do not apply. They include urbanized areas, streams affected by regulation or diversion by works of man, unforested areas, streams with gaining or losing reaches, streams draining alluvial valleys and the Snake Plain, intense thunderstorm areas, and scattered areas where records indicate recurring floods which depart from the regional equations. Maximum flows of record and basin locations are summarized in tables and maps.

The analysis indicates deficiencies in data exist. To improve knowledge regarding flood characteristics in poorly defined areas, the following data-collection programs are recommended. Gages should be operated on a few selected small streams for an extended period to define floods at long recurrence intervals. Crest-stage gages should be operated in representative basins in urbanized areas, newly developed irrigated areas and grasslands, and in unforested areas. Unusual floods should continue to be measured at miscellaneous sites on regulated streams and in intense thunderstorm-prone areas. The relationship between channel geometry and floodflow characteristics should be investigated as an alternative or supplement to operation of gaging stations. Documentation of historic flood data from newspapers and other sources would improve the basic flood-data base.

\section{INTRODUCTION}

Man must acquaint himself with the characteristics of floods if he is to control them. Determination of the magnitude and frequency of floods in small streams is needed for the planning and design of hydraulic structures and related facilities. Specifically, knowledge of flood potential is required for the economic design of dams, bridges, highways, culverts, and levees; for management of flood plains and flood water; and for environmental impact studies.

As a first step toward acquiring knowledge indicative of peak floodflows in small streams in Idaho, the U.S. Geological Survey, in cooperation with the Idaho Department of Highways, the Idaho Department of Water Administration, and the U.S. Forest Service, initiated a project in 1961 whose goal was to collect and interpret the needed peak-flow data. This report summarizes the information gained by this project. Although many agencies and people contributed to the data collection, compilation, and analysis, special acknowledgment is made of the technical guidance furnished by D. M. Thomas, H. F. Matthai, and H. C. Riggs, of the Geological Survey. 


\section{Purpose and Scope}

The purpose of this report is to describe a method of estimating magnitude and frequency of floods for small streams in Idaho. Available streamflow records indicate a wide range in watershed response to precipitation and snowmelt and, thus, in the flood potential of small basins. Records of sufficient length, 10 years or longer, or measurements of extreme flood events may be more representative of discharge at many sites than values estimated by methods used herein. However, obtaining records sufficiently long at each site on small streams where flood data are desired is economically unfeasible because of the large number of small basins involved. When adequate on-site data are not available and the collection of records of sufficient length is not justified, probably the most reliable basis to date for estimating flood expectancy is the method outlined herein. However, the U.S. Geological survey is continuing investigation of other methods as more data and new techniques become available.

Many methods have been proposed for estimating flood discharges in small basins. These methods have been summarized by Dalrymple (1964) as follows:

"Empirical methods for computing flood discharges have been, and are, widely used. Over 100 such formulas have been proposed. Most, if not all, of these are inadequate in evaluating the hydrologic factors involved. The increasing accumulation of records of discharge of streams draining small basins has decreased the need for these empirical formulas, and they are being supplanted by more logical methods.

"Results of statistical analyses of flood records, involving computation of regional flood-frequency curves, are being used increasingly as such information becomes available. This is a logical procedure, since it makes use of the large amount of discharge data that is being collected at many gaging stations. This method is preferable to the others ..., but its use for small drainage basins is handicapped by the deficiency of data."

The various empirical methods previously used to predict flood expectancy for small, streams have not necessarily been based on flow characteristics of Idaho streams, and are likely to give results considerably different from what will actually be experienced. The credibility of most of these empirical methods has never been established as no quality checks have been provided.

The method described in this report is based on all of the usable records from basins with continuous-record gaging stations and with drainage areas less than 500 square miles, and on the 
records from crest-stage stations. In addition, measurements of unusual floods at miscellaneous sites have been used as a guide in the analysis and in the application of the method. Streamflow records at sites significantly affected by regulation or diversion or those which are significantly affected by large interchanges with ground-water systems were not used.

The 10-year flood was determined for all usable sites in or near Idaho. A relatively large number of basin characteristics were determined for each basin in Idaho where sufficient flood record was available. Only five of these basin characteristics were incorporated in the recommended regression relations. These characteristics and the magnitude and frequency of floods were defined using multiple regression relations. It was assumed that the relationships based on records at gaged sites could be used to estimate the magnitude of floodflows at ungaged sites using the basin characteristics of the ungaged sites.

The standard error of estimate was determined for each relationship and was used as a basis for judging the probable accuracy of the peak-flow estimate.

The large number of basin characteristics investigated was simplified and reduced to make the method more practical. objectivity and the law of diminishing returns justify some sacrifice in the accuracy of the flow estimate. Regression equations containing all significant variables as well as the flow and basin characteristics for the stations used are available at the Idaho district office in Boise.

\section{Previous Studies}

A series of reports entitled "Magnitude and Frequency of Floods in the United States" was published in Water-Supply Papers of the U.S. Geological Survey. These reports include all flood data available through the 1957 water year and the methods presented in them for determining floods at ungaged sites were the best that the state of the art and the available data then allowed. Lists of peak stages and discharges for all gagingstation records more than 5 years in length were compiled. All streams in Idaho are located in one of three major river basins or "Parts" as defined by the U.S. Geological Survey. Each report covered a "Part" as follows: Water-Supply Paper 1684 was for The Great Basin (Part 10), Water-Supply Paper 1687 was for the Upper Columbia River Basin (Part 12), and Water-Supply Paper 1688 was for the snake River basin (Part 13).

The Geological Survey open-file report entitled "A Proposed Streamflow-Data Program for Idaho" presents an analysis of the magnitude and frequency of floods as well as other streamflow 
parameters. All stations having 10 years or more of record at the end of the 1967 water year were used. Many records on small streams, including those for the crest-stage gages, were not yet of sufficient length to use in that report.

Results from methods outlined herein are more dependable than those developed from previous studies for basins smaller than 200 square miles since the data base has been expanded considerably and techniques have been improved.

\section{DESIGN METHOD}

Subject to the limitations outlined beginning on page 13 peak discharges at selected recurrence intervals can be determined for small streams as follows:

1. Locate the site on the map of figure 1 and determine if a gage has been operated nearby on the same stream. An explanation of the gaging-station-numbering system used by the U.S. Geological survey is on page 25 and, for convenience, in figure 1. If a gage site is located nearby on the same stream and the basin characteristics above the gaged and ungaged sites are relatively homogeneous, check table A-2 for a peak discharge at the desired recurrence interval at the gaged site and adjust the peak to the ungaged site on the basis of drainage area. If the stream has not been gaged nearby, inspect figure 1 to determine if the basin is outside the undefined areas, and if so, determine in which region the site is located.

2. By inspection of the applicable regression equation in table $A-1$, determine which basin characteristics are needed. A description of the equation symbols and methods of determining the basin characteristics starts on page 6 .

3. Determine the required basin characteristics from the best

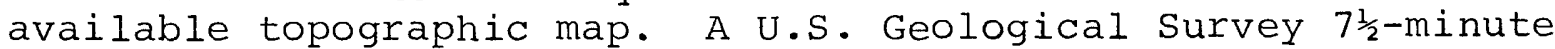
topographic map is suggested. Complete coverage of the state is available in the U.S. Geological Survey 1:250,000 scale map series. Determine the forest cover (F) which is needed for evaluation purposes, even though it may not appear in the equation.

4. Having determined the basin characteristics, use the appropriate nomograph, figures $A-1$ to $A-8$, or the regression equation from table A-1 to compute the peak discharges at 10-, 25-, and 50-year recurrence intervals.

Nomographs are provided for computing peak discharges for small basins between 1 and 50 square miles. Regression equations are valid for drainage basins from 0.5 to 200 square miles. 
5. Investigate further to determine if limitations apply that invalidate use of the regression equation or if adjustments to the discharge should be made which would improve the design discharge ( $p$. 13-19). Check peak discharges for reasonableness by comparing with peak discharges of record for nearby streams. See examples on pages 8-11.

\section{Basin Characteristics}

Descriptions and methods of determination of the five basin characteristics used in the regression equations are given below:

Drainage area (A), in square miles, is determined by outlining on the best available topographic map the surface-water divide upstream from the point of interest on the stream, and determining the area from the map using a planimeter. U.S.

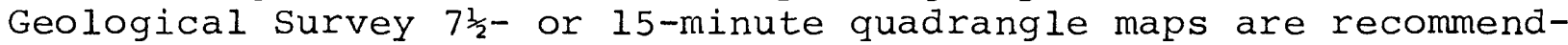
ed when available.

Forest cover $(F)$ is expressed as the percentage plus 1 percent of the drainage area covered by forests and is determined from a U.S. Geological Survey 1:250,000 scale map. A recommended procedure is to lay a grid over the basin outline, count the number of grid intersections lying within the forested (green) areas and the number of grid intersections within unforested areas, and from this calculate the percentage of the basin that is forested.

Area of lakes and ponds ( $\mathrm{La}$ ) is expressed as the percentage plus 1 percent of the drainage area covered by water (lakes, ponds, or swamps), and is determined by the grid method. See

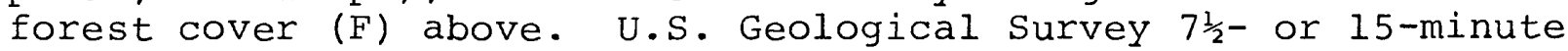
quadrangle maps are recommended when available.

Latitude (N) is the latitude of the centroid of the basin, in decimal degrees minus 40 degrees. It is determined from inspection of the basin as outlined on a U.S. Geological Survey $1: 250,000$ scale map.

Longitude $(W)$ is the longitude of the centroid of the basin in decimal degrees minus 110 degrees. It is determined from inspection of the basin as outlined on a U.S. Geological Survey $1: 250,000$ scale map.

\section{Relative Magnitude of Floods}

Comparison of estimates of floods at ungaged sites with the maximum floods known is useful in evaluating the relative magnitude and to ascertain the credibility of the estimates. The 
maximum known flood is often used as the design flood. Relative magnitudes of flood events are desirable for use in both planning and design.

The maximum discharges of record for streams in Idaho which are significant for comparative purposes are plotted against drainage areas in figure 3. The plot includes significant maximum discharges at miscellaneous sites as well as at short-term gaging stations. The plot also shows the wide range of peak discharges which have been recorded. Peak discharges as computed by the outlined method should be checked for credibility by plotting on the graph and comparing with the flows experienced at nearby stations. Only the stations with maximums of record greater than $100 \mathrm{cfsm}$ (cubic feet per second per square mile) have been identified by station number. A specific site in tables $A-2$ and $A-3$ can be identified on the graph using the drainage area and maximum discharge from the tables.

For comparative purposes, three curves are shown in figure 3. The Matthai curve (Matthai, 1969, p. B6) is an average through the highest known floods recorded in the United States up to 1965. The Hoyt and Langbein curve (Matthai, 1969, p. B6) is an average through the maximum floods recorded prior to 1950, and the Creager, Justin, and Hinds curve (Matthai, 1969, p. B6) is an average through the maximum known flood data available in 1890 . Concerning the increase between the 1890 and 1950 curves, Hoyt and Langbein stated (Matthai, 1969, p. B6) "This is no evidence that flood conditions are changing. The upward shift of the curves ... is due entirely to an increased number of gaging stations and increased period of record."

As more records become available, the upper limits of the maximum known flood plot will move upward as additional rare floods are measured. Nevertheless, figure 3 is indicative of what can be expected in the future.

Generalizations regarding magnitude and frequency of floods in Idaho can be made from figure 3. Floods greater than about 300 cfsm have rarely been observed on basins greater than 4 square miles. Most floods having rates greater than $300 \mathrm{cfsm}$ occur in unforested basins, a few of which have been denuded by range fires. This large a flow has been recorded at only one site on a forested basin, Canyon creek tributary near Lowman (M13234215), and there the forest cover was light. All floods greater than $300 \mathrm{cfsm}$ were from intense thunderstorms and were unassociated with snowmelt. All basins with floods greater than $100 \mathrm{cfsm}$ have drainage areas less than 40 square miles, and only five of these floods were not caused by intense thunderstorms. Conversely, a flood greater than $100 \mathrm{cfsm}$ has not yet been recorded in Idaho on a basin larger than about 40 square miles. Evidently, floods which plot to the left of any of the three curves in figure 3 have long recurrence intervals and are rare. 


\section{Examples}

The following examples illustrate the application of the design method.

Example 1

Determine the 10-, 25-, and 50-year floods for Bloom Creek at the mouth near Bovill.

Step 1. The mouth of Bloom creek is in sec. 3, T. 4 I N., R. I E., and the basin is entirely on the U.S. Geological Survey Bovill 15-minute quadrangle map. A continuous-record gage (station 13341300) was operated at the site (fig. 1). Records are available from 1959 to 1971. Figures of peak discharge through the 20-year flood computed by the log-Pearson Type III method as modified (see p. 19) are listed in table A-2. A check of figure 1 indicates the design method applies. The site and basin are in Region 1 .

Step 2. Table A-I indicates drainage area (A) is the only basin characteristic that needs to be determined for the Region 1 regression equation. Forest cover ( $F$ ) also should be determined for evaluation purposes.

Step 3. The drainage area for Bloom Creek as previously determined by planimetering from the Bovill quadrangle is 3.15 square miles. Forest cover $(F)$ is determined to be 101 .

Step 4. Using either the nomograph or the regression equation and the ratios for Region 1 , the 10-year flood is found to be about $135 \mathrm{cfs}$, the 25-year flood is about $175 \mathrm{cfs}$, and the 50-year flood is about $200 \mathrm{cfs}$.

From table $A-2, Q_{10}$ by the modified log-Pearson Type III method for Bloom creek is 133 cfs, which closely checks the figure from the nomograph and the equations.

Step 5. No limitations appear to apply to this stream. None of the basin is urbanized. Forest cover index is 101, well above the recommended minimum requirement of 30 (see p. 14) for application of the $Q_{25} / Q_{10}$ and $Q_{50} / Q_{10}$ ratios. No regulation or diversion which aftects the peaks is known. Base flow (the flow after direct runoff from rain or snowmelt has stopped) as observed in late summer is low, indicating no significant effect from ground-water runoff. Alluvium, lava flows, or intense thunderstorms do not appear to affect this area significantly. Also, there are no anomalous areas nearby. Discharge plotted against drainage area in figure 3 appears reasonable compared 
with plots for nearby streams. For example, a crude check of the data is provided by plotting the $175 \mathrm{cfs}$ ( $Q_{25}$ for Bloom Creek) against its drainage area ( 3.15 square miles) and comparing it with a plot of $Q_{25}$ versus drainage area for East Fork Potlatch River (13341400) and other basins nearby. They appear to plot near the same position with respect to the $100 \mathrm{cfsm}$ line.

\section{Example 2}

Determine the 25-year flood for a site on Targhee Creek below the confluence of the East Fork with Targhee Creek.

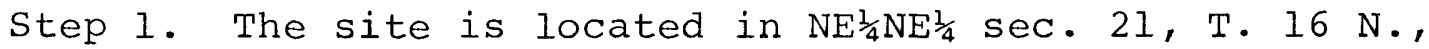

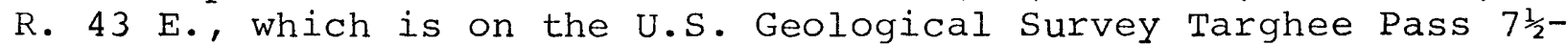
minute quadrangle map. The basin lies on Targhee Pass and Targhee Peak 7/2-minute quadrangle maps and the Hebgen Dam 15minute quadrangle map. A crest-stage gage (station 13038900) was operated from 1963-71 at a site 5 miles downstream (fig. 1). From figure 1, the site and basin are in Region 6 .

Step 2. Table $A-1$ indicates the basin characteristics to be determined are area (A), area of lakes and ponds (La), and latitude of the basin centroid (N). Forest cover should be determined for evaluation purposes.

$$
\begin{aligned}
& \text { Step 3. } \mathrm{A}=10.5 \\
& \mathrm{La}=0.4+1.0=1.4 \\
& \mathrm{~N}=4.7 \\
& \mathrm{~F}=44+1=45
\end{aligned}
$$

Step 4. Using the appropriate nomograph (fig. A-6) or the regression equation, a 25-year flood of 136 cfs is indicated. The details of the computation using the regression equation are as follows:

$$
\begin{aligned}
Q_{10} & =188 \mathrm{~A} 0.873 \mathrm{La} 0.773 \mathrm{~N}^{-1.82} \\
& =188 \times 10.50 .873 \times 1.40 .773 \times 4.7^{-1.82} \\
& =188 \times 7.79 \times 1.30 \times 0.060=113 \mathrm{cfs} \\
Q_{25} & =113 \times 1.2=136 \mathrm{cfs}
\end{aligned}
$$

The peak discharges should be rounded to two significant figures but were used as computed for ease of checking.

Urbanization or regulation do not affect the peaks. Small diversions for irrigation probably do not affect the peaks because peaks normally occur before the irrigation season. Base flow as observed in late summer is low, indicating no significant effect from ground-water runoff. Alluvium and lava flows do not appear to alter the peak characteristics. 
The relative magnitude of the $Q_{25}$ from the nomograph can be compared with a $Q_{25}$ for the crest-stage gage on Targhee Creek (13038900). From table A-2, Q10 for Targhee Creek is $335 \mathrm{cfs}$. Using the regional ratio for Q10/Q25 of $1.2, Q_{25}$ equals $335 \mathrm{x}$ $1.2=402 \mathrm{cfs}$. The ratio of the drainage areas at the subject site and the crest-stage gage site is $10.5 / 20.8$ or 0.50 . On the basis of the drainage area ratio and the record at the creststage gage, $Q 25$ at the subject site would be $402 \times 0.50=201$ cfs. This is 48 percent greater than the $136 \mathrm{cfs}$ from the nomograph. In region $6, Q_{50}$ is only $I . I$ times $Q_{25}$; therefore, the design flood might be chosen on basis of maximum discharges at nearby sites rather than that for a selected recurrence interval. In figure 3, maximum discharges at nearby stations, including stations 13113000, 13047800, and 13051500, plot above and below the $Q_{25}$ of $136 \mathrm{cfs}$. Because the relation with the gaging station on Targhee creek indicates a higher discharge and since maximum discharges at several nearby sites are considerably higher, a conservative discharge may be obtained by increasing the Qlo discharge by one standard error, or 41 percent. See table A-1.

$$
\text { Design discharge }=1.41 \text { (113) } 1.2=191 \mathrm{cfs}
$$

\section{Example 3}

Determine the 50-year flood for Cottonwood Creek at the mouth near Horseshoe Bend.

Step 1. The site is in sec. 3, T. 6 N., R. 2 E., which is

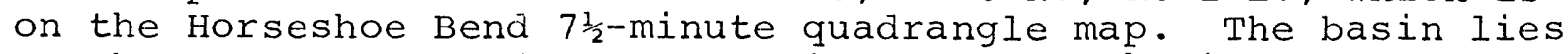
on the Horseshoe Bend and Cartwright Canyon $7 \frac{1}{2}$-minute quadrangle maps. A crest-stage gage (station 13248900) was operated at this site from 1961 to 1971. From figure 1 the site is in Region 3.

Step 2. Table I indicates the basin characteristics to be computed are area (A), forest cover (F), and latitude of the basin centroid (N).

$$
\begin{aligned}
\text { Step 3. } & A=6.53 \text { square miles } \\
F & =0+1.0=1.0 \\
N & =3.85
\end{aligned}
$$

Step 4. The nomograph gives a $Q_{50}$ flood of $440 \mathrm{cfs}$. Using the regression equation, the 10 -year flood is

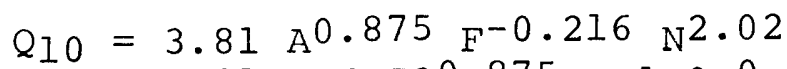

$$
\begin{aligned}
& =3.81 \times 6.530 .875 \times 1.0-0.216 \times 3.852 .02 \\
& =3.81 \times 5.16 \times 1.0 \times 15.2=300 \mathrm{Cfs} \\
& \text { and } Q_{50}=300 \times 1.5=450 \mathrm{cfs} \text {. }
\end{aligned}
$$


Step 5. Urbanization or regulation do not affect the peaks. Field inspection indicates that some flow will bypass the site during extreme floods. Peaks generally occur during the winter and would not be affected by irrigation diversions.

The channel is dry for long periods indicating that no large springs feed the stream. The generalized geologic map of Idaho (Ross, 1947) shows that about 40 percent of the basin is on granitic rock, which is relatively impermeable and about 60 percent is on the weakly consolidated continental sedimentary rocks which are variable in permeability from one location to another. Coarse alluvium or fractured lava deposits are not extensive. Extreme floods from thunderstorms have been recorded within 20 miles to the southeast (fig. 2). There is no significant forest cover on the basin, and forest cover $(F)$ is $0+1=1$. Q10 of $220 \mathrm{cfs}$ by the modified log-Pearson Type III method is reasonably well defined by 10 years of record. However, the Q50/Q10 ratio is not well defined for this or other unforested basins in any reyion of the state. Comparison with plots of discharge for nearby streams in figure 3 also indicates a wide divergence of peak flows for this area.

Because of uncertainties of the definition of discharges at long recurrence intervals, the designer should consider several alternatives. No intense thunderstorms have been recorded in the immediate area, although some have been experienced just over the ridge to the south [see site M13207650 (fig. 2 and table A-3) and others on the Boise front, near Boise (fig. 2)]. In addition to the thunderstorm floods nearby, maximums for Big Willow Creek near Emmett, Fourmile Creek near Emmett, Bryans Run near Boise, Spring Valley Creek near Eagle, and the magnitude and frequency data for the subject site should be considered in assessing the flood potential and risk at long recurrence intervals.

A reasonable design discharge for all but the extremely rare events could be determined by increasing the Q50 discharge by percentages equivalent to one standard error as follows: Q50 at the site was determined to be $450 \mathrm{cfs}$. Standard error for Region 3 is 51 percent. Increasing 450 by 51 percent gives a more conservative discharge of $680 \mathrm{cfs}$. If damage would be extreme from a structural failure, a discharge equivalent in percent to some larger multiple of the standard error may be added to the discharge from the nomograph.

\section{ACCURACY AND IIMITATIONS}

The method described herein should be used with full know1edge of the applicable limitations. Sites where the method should not be used are described in a later section. 
The accuracy of the relationships for predicting flood potential depends on the adequacy of the data base in time and space. Gaging-station data should be long enough to define a reasonable index of the long-term flood potential. In addition, the areal distribution of gaging stations should be sufficient to sample the range of basin and climatic characteristics in Idaho so that the relations will be defined adequately. Records used herein were not adjusted to a common base period. The sampling of flow characteristics, especially with short records, is probably more representative if the samples are not for the same period at all sites. Several large areas in which areal coverage is light and definition of basin characteristics are probably inadequate are indicated by inspection of figure 1 .

Extrapolation beyond the limits of reasonable statistical definition of the data base is not advised. Regression equations should be used only for drainage areas larger than 0.5 square mile and smaller than 200 square miles.

Prior to 1971, the peak flow data available were inadequate to define peak flow characteristics of small streams. For WaterSupply Papers 1684, 1687, and 1688, "Magnitude and Frequency of Floods", records of peak flows for only 35 sites in Idaho for basins smaller than 50 square miles were long enough to compile and use in the study. To make the data base adequate, the U.S. Geological Survey began a data-collection program in 1961.

Since then, about 80 crest-stage gages and six continuous-record gaging stations have been operated. In addition, records have been obtained by the U.S. Geological Survey and by other agencies at many sites, and peak discharges of unusual floods at 155 sites have been measured using indirect methods. A total of 303 records for small streams in or near Idaho were sufficiently long for statistical use and were analyzed in this study. Results of the miscellaneous measurements of unusual floods were useful for guidance in the analysis.

Staff hydrologists of the Geological Survey recommend that records of peak discharge should not be used to estimate floodflows for recurrence intervals longer than twice the period of record. By this standard, the crest-stage gage records, which average about 10 years in length, are not long enough to define adequately floods for frequencies beyond 20 years. Accordingly, figures of discharge for recurrence intervals greater than 20 years are not given for many sites in table $A-2$. Using the above criterion, only a few of the records on small streams are long enough to define the 50-year flood. Yet values for the 50-year flood are required for the design of many structures and the 100and 200-year peak discharges are required for flood insurance studies and for sites where potential loss of life may be involved. 
The standard error of the estimate for a floodflow is useful as a basis for increasing the design discharge at sites where underdesigning would cause excessive damage or where a conservative design or additional factor of safety is desired. Increasing the QI0 discharge determined from the regression equation by percentages equivalent to one or two standard errors provides a factor of safety which would lessen the chance of a structural failure.

Standard errors of estimate shown in table A-l indicate how well the regional regression equation fits the determinations of $Q_{10}$ from station records. By definition, about two-thirds of the $Q_{10}$ 's determined from the gaging-station records are within one standard error of the $Q_{10}$ as determined from the regional regression equation. In other words, about one-third of the Q10's determined from the gaging-station records are more than one standard error away, either plus or minus, from the $Q_{10}$ based on the regression equation.

\section{UNDEFINED AREAS WHERE REGRESSION RELATIONS DO NOT APPLY}

Regional regression relations should apply to areas which are homogeneous with respect to variables which affect the flow Regression equations may not apply to basins in which the basin, or flow, characteristics are outside the range of those characteristics used to define the regional regression relations. Variations in topography, climate, geology, land use, and regulation of streamflow in Idaho often result in abrupt changes in flow and basin characteristics. Some of these variations are inadequately defined by available data. The following sections describe the poorly defined areas and discuss the reasons the regression relations are inapplicable.

Areas in which regional regression relations are not defined total about 20,000 square miles and are outlined in figure 1 . In addition to these areas, smaller undelineated areas are scattered throughout the state.

In general, the undefined areas are mostly arid or semiarid. Streamflow in small streams is usually ephemeral (flowing only in direct response to precipitation or shortlived snowmelt) or intermittent (flowing only part of the time, such as during the snowmelt period or during wet periods in winter). Records are sparse and short in length. Therefore, floodflow magnitudes and frequencies have not been defined.

In addition to areas of poor definition, peak flows in many small basins are affected by urbanization, regulation, significant quantities of ground-water runoff, large losses or gains 
associated with alluvial valleys and lava flows, intense thunderstorms, unusual climatic or physical basin characteristics or a combination of these factors.

Unforested areas

Most of the unforested areas of the state are in the arid or semiarid areas where precipitation is too low to support forestation. Nearly all of the area designated as undefined in figure 1 is unforested. Small streams are usually ephemeral or intermittent, and the volume of runoff is low. Only a few records are available to define the magnitude and frequency of floods on these areas, and very few records are available to define the $Q_{25} / Q_{10}$ and $Q_{50} / Q_{10}$ ratios.

Since a small percentage of forest cover appears to be indicative of the ephemerality of streams in small basins, basins with less than 30 percent forest cover $(F<30)$ are assumed not defined by methods used in this report.

Judgment and the maximum unit discharge of record for nearby streams, as shown in figure 2, are the best bases that can be recommended for the determination of discharge in unforested basins.

\section{Urbanized Areas}

Urbanization drastically changes basin features of which increase in paved areis and the addition of sewerage are the most obvious. Both decrease the concentration time of the basin, which increases the intensity of floods and the frequency of flooding. Climates have been observed to change in or near large cities. Precipitation, temperature, humidity, cloudiness, and wind speed may be altered to some degree in urban areas. Also, urbanization is often accompanied by infringements on the natural flood channel and the flood plain, thus increasing flood heights. On the other hand, storm sewers may bypass surface flows past some sites, thus reducing peaks in natural channels.

Studies in other parts of the country indicate that for a basin of 1 square mile that is completely storm sewered and whose surface is completely or 100 percent impervious, the mean annual flood (approximately the 2-year flood) is about eight times larger than for the natural basin. The mean annual flood from a basin of 1 square mile that is completely storm sewered but zero percent impervious is about 1.7 times as large as for the natural basin. 
The mean annual flood for a basin which is completely impervious but not sewered is about 2.5 times as large as for the natural basin (Leopold, 1968). Very little information of this type is available regarding discharges from urbanized areas in Idaho.

Regulated Streams

South of about $45^{\circ} 30^{\prime}$ north latitude, most agriculture, except grazing and dry farming, requires irrigation. Roughly 5,500 square miles, or nearly 7 percent of the total area of the State, is irrigated, of which nearly 80 percent is irrigated from surface streams. Irrigated areas in the state are shown in figure 1 .

Streams which reach the irrigated lands may be affected by one or a combination of the following: Regulation, diversion, consumptive use, and return flow from irrigation. The impact on natural flood peaks is significant. Peak flows in many natural channels are drastically reduced, and regional regression equations usually do not apply directly.

Determination of realistic design discharges requires that manmade effects be considered. Sources of data for estimating peak flows in these streams include records of performance of existing structures such as canals, bridges, ditches, drains, etc.; watermaster records of water use; streamflow records; verbal reports from local residents; and estimates of natural peak flows using basin characteristics. Contributing areas upstream during flood periods are sometimes difficult to define because of storage in reservoirs or upstream diversions which may divert flood water outside the basin. Composite effects from works of man including canals, roads, levees, dams, and storage behind fills during floods are difficult to evaluate. Only a few floods have been measured in channels of this type and most of these have been on large streams. Flows in Morse creek (13301800), Twelvemile Creek (13302200), Spring Valley Creek (13207000), and Robbers Roost Creek (13073700) in table A-2 are known to be affected by diversions above the gaging sites. Likewise, floods in "D" drain tributary (M13084800) and "F" drain and some others listed in table A-3 may be affected in varying degrees by works of man.

Streams with Losing or Gaining Reaches

A large number of streams, both large and lose flow by interaction with the ground-water system. Streams flowing over permeable formations tend to gain in discharge if 
they are below adjacent ground-water tables and lose if above them. These streams are especially common in the areas marked "undefined" in figure 1. The characteristics of floods in such streams can be very different from streams fed more directly by overland flow.

Peaks in gaining reaches may be greatly subdued because all or part of the peak flow originates from ground-water runoff which is regulated by slowly changing water tables. For example, the discharge of Birch Creek near Reno (13117000) is practically all ground-water runoff which originates a few miles above the gage. The maximum flow in 15 years of record is 220 cfs (table A-3). This peak flow is only 2.8 times the average discharge for the period of record. The channel is usually dry over the alluvium above the reach of discharge from ground water. The stream then loses below the gage, never flowing past the Birch Creek Sinks, about 30 miles downstream. A more normal stream nearby, Sawmill Creek near Goldburg (13117300), has a maximum flow of $651 \mathrm{cfs}$ in 10 years of record, which is 13.4 times its average flow for the period.

Other streams, such as Cub River near Preston (10093000), and Birch Creek near Downey (13074000) are fed by large underground flows coming from solution cavities in limestone mountains and respond relatively quickly to changing rates of snowmelt. They may drain areas much larger or smaller than their surface drainages indicate. Floodflows in such streamis may be at high rates while the flooding in adjacent streams may be considerably smaller.

A decrease in flood discharge occurs in many small streams as they flow from the impervious rocks of the mountain ranges onto the alluvial valleys. Peak flows are often further decreased by diversion for irrigation. For example, the maximum discharge of record for Morse Creek above diversions, near May (13301700) is $230 \mathrm{cfs}$, while the maximum for Morse Creek near May (13301800), 2.7 miles downstream, across an alluvial fan, and below irrigation diversions, is 81 cfs.

Stream channels known to be affected by significantly large gains or losses are shown in figure 1. Data other than, or in addition to, the discharge determined by regional regression equations are needed in these areas.

\section{Alluvial Valleys and the Snake Plain}

Closely related to the streams with losing or gaining reaches discussed previously are streams draining basins entirely in alluvial or glacial valleys or on the Snake Plain. Other 
basins include both mountain and valley areas. Large areas of intermontane valleys and lowlands are underlain by deep alluvium. Other areas, especially the snake Plain, are underlain by fractured basalt, and both types of formations can absorb large quantities of flood water. Percolation rates are considerably reduced by deep soil cover or by lacustrine deposits, both of which vary considerably in thickness, extent, and permeability.

In most years, floods are not generated on the alluvial valleys and plains because the rate of infiltration greatly exceeds the snowmelt or precipitation rate. Natural streams are ephemeral unless the channel intercepts the ground-water table, in which case the stream is intermittent or perennial. Large parts of the Snake Plain are unchannelized or have very poorly developed channels, indicating that overland flow may be rare and shortlived.

Occasionally as snow melts, the melt water freezes in place, and a glaze is formed over the permeable alluvial or basaltic surfaces, making the surface very impermeable. If more snow accumulates and a quick snowmelt then occurs, high rates of runoff result. The floods of February 1962, February 1963, and December 1964 resulted from this sequence of hydrologic conditions, and caused extensive flooding on the lowland areas of southern Idaho. Many miscellaneous measurements of these flood discharges were obtained and are shown within basin boundaries (see fig. 2). The measurement results are listed in table A-3. No frequency data are available for this type of flood, but the data are indicative of the size of flood which can be expected from this type of event.

Much of the irrigated land in the state is in this area, and natural streams are usually affected by regulation, diversions, return flow, or changing land use. (See section on regulation and figure 1.)

\section{Intense Thunderstorm-Prone Areas}

Intense thunderstorms may produce rates of runoff in small basins which are much higher than those computed using the regression equation. Of the peak discharges listed in table A-3, those which were summer floods and were not associated with snowmelt were assumed to be caused by intense thunderstorms. Of these, 11 discharges exceeded 1,000 cfsm of which three were higher than 5,000 cfsm. Five more measurements showed rates between 500 and $1,000 \mathrm{cfsm}$, and 13 showed rates between 100 and $500 \mathrm{cfsm}$. Reference to figures 2 and 3 and the "Relative magnitude of floods" section indicates that most of the extremely 
high rates of runoff of record in Idaho are caused by intense thunderstorms. Storm cells are often small and may be confined to a small part of the basin.

All of the intense thunderstorm-prone areas measured to date are essentially unforested except Canyon Creek tributary near Lowman, which is only sparsely forested. Practically all of the extreme floods caused by thunderstorms which have been documented are in southern Idaho near the Snake Plain except for a few floods near Lewiston. Areas near the Boise front, in the Portneuf-Bear River section, and near American Falls, Murphy, Bruneau, and Lewiston appear to be prone to flooding of this type. Most intense thunderstorms appear to occur near the foothills or the base of the mountains adjacent to extensive valley areas such as the Snake Plain, Cache Valley, or Columbia Basin.

No series of annual peak flows has been established for any of these intense thunderstorm-produced floods, and recurrence intervals have not been established. Probably the best basis for establishment of recurrence intervals at a design site would be from newspaper or other local accounts. Hazard from this type of flood does exist and should be considered when designing structures for several areas of the state.

Anomalous Areas

Variations in topography, geology, climate, and land use are extreme in the State. The basin characteristics determined do not define all combinations of these variables, and the effects of the variables on floodflows have not been defined by the limited number of sites where flow data have been collected. The discharges given by the simplified equations proposed do not fit all the records of discharge within reasonable limits. The actual discharge for a given recurrence interval for some ungaged streams will likewise be more or less than the discharge given by the regression equations of this report.

Table A-4 is a list of the gaged sites for which the Q10, determined by the modified log-Pearson Type III method, exceeds or is less than the Q10 from the regression equations by more than 70 percent. Reasons for departures from regional data are not always apparent, but at nearly all sites listed in table A-4 several flood events have been recorded that exceeded or were less than the regional 10 - or even 50-year peaks as determined by the applicable regional equations. Reference to table A-4 will enable users to determine areas where peaks of record are well above or below the estimated discharges using the regional equations. 
The percentage of departure of an anomalous area from the regional data can be used as a guide in the application of the regional data to ungaged small streams. Estimates of peak flow for streams within anomalous basins, or for nearby basins which appear to have similar flow or basin characteristics can be raised or lowered accordingly, especially if under-designing or over-designing would result in extensive damage or prohibitive costs.

\section{ANALYTICAL TECHNIQUES}

\section{Magnitude and Frequency of Floods at Gaged Sites}

The plot of maximum known floods (fig. 3) shows that rates of peak discharges range widely from place to place in the State. The lower enveloping curve is near 1 cfs per square mile, and the upper curve is more than 5,000 cfs per square mile. This wide spread suggests that adequate areal definition requires data at many sites. For this reason, all peak flow data from gaging stations operated for more than a few years were extended, if practicable, to about 10 years by simple linear regression with similar streams nearby.

The log-Pearson Type III method (a statistical distribution) and a digital computer were employed to determine the magnitude and frequency of floods at the 303 study sites. The log-Pearson Type III method has been adopted by the Water Resources Council (1967) as a uniform nationwide technique for the determination of magnitude and frequency of floods. The log-Pearson Type III magnitude-frequency relation and the annual maximum series relation using the recorded peak data were plotted on an extremevalue frequency graph. These relations were then compared and analyzed for conformity and were adjusted when necessary. It is characteristic of the log-Pearson Type III method that "outliers" affect the shape of the relation thoughout the range. For example, if the lowest annual peak of record at a given site is far below the second lowest annual peak of record, the upper end of the relation curve tends to flatten noticeably. The floods of record in many streams in Idaho appear to follow a different trend. Snowmelt floods define a relation with a low coefficient of variation (or a curve with a flat slope). Occasionally, great storms occur, sometimes when the ground is frozen or covered with snow. Thunderstorms, rain on snow, or combinations of these events, cause floods which indicate the flood-frequency relations should curve upward at the upper end (see Hazen, 1930, p. 104). When several events during the period of record plot to the left of the log-Pearson curve, for example, the log-Pearson relation was modified to fit the recorded data better. Data from miscellaneous measurements of unusual floods were useful as guides in 
the analyses. The peak discharges at selected frequencies so computed for all stations in this study with drainage basins smaller than about 50 square miles are given in table A-2.

\section{Multiple Regression Model}

The magnitude of peak flows at selected frequencies $\left(Q_{5}\right.$, $\left.Q_{10}, Q_{25}, Q_{50}, \ldots\right)$ were related to the basin and climatic characteristics with equations developed using multiple regression techniques. A digital computer was used to perform the voluminous calculations for the stepforward and stepbackward multiple regression analysis.

The model used assumes that the form of the relation between a peak flow characteristic, $Q_{10}$, for example, and the basin characteristics $\left(A, S, F\right.$, etc.) is $Q_{10}=m_{A} a_{S} S_{F} f \ldots$ where $m, a$, $s$, and $f$ are constants determined by regression. The stepbackward method of multiple regression was employed using a single flow characteristic and one or more basin characteristics to determine a regression equation. The standard error of estimate, the statistical significance of each basin characteristic and other statistical data were also determined. The least significant basin characteristic was then omitted and the calculations repeated. This process was continued until a relation containing only the most significant basin characteristic remained. After a set of equations was computed for a selected flow characteristic, say $Q_{10}$, another flow characteristic, say $Q_{25}$, was used, and the process was repeated.

of the peak flow characteristics investigated, the regression equation for $\mathrm{Q}_{10}$ showed the smallest standard error. The $\mathrm{Q}_{10}$ flow characteristic determined, as explained previously, by the modified log-Pearson Type III method was reasonably well defined by records of peak flow at most of the gaging stations used in the analysis.

Further analysis of the data was made using the stepforward method of multiple regression. In this method, the most significant basin characteristic is determined first, followed by the second and others until all basin characteristics that are significant at a prespecified level have been added to the regression equation. At this time, the residual was also determined for each flow characteristic. The residual is an indice of departure from the expected (see Glossary, p. 30).

An analysis of the ratios of peak flows at selected frequencies was made to investigate whether these ratios would relate peak flow at short recurrence intervals, say $Q_{10}$, to peak flows at long durations, say $Q_{50}$. This investigation was desirable 
since the peak flows for long recurrence intervals are not well defined by gaging-station records for small streams.

Several ratios of peak flows at various frequencies, as determined by the modified log-Pearson Type III method, were computed for each station and were regressed with the basin characteristics. Of the ratios investigated, the Q25/Q10 and $Q_{50} / Q_{10}$ ratios were better defined than were ratios using index floods other than $Q_{10}$ (say $Q_{25} / Q_{2}, Q_{50} / Q_{2}, Q_{25} / Q_{5} \ldots$... . Therefore, the $Q_{10}$ flow characteristic and the ratios associated with it were used as a basis for regionalization and for the determination of the $Q_{25}$ and $Q_{50}$ flow characteristics.

Results of multiple regression analyses showed that residuals from the relations had geographic groupings and indicated a need to subdivide the state into regions. The data for each region were then analyzed separately. Studies of numerous regional variations indicated that the eight regions shown in figure 1 provided the most reasonable fit to the available data.

Q10 regression equations for each of the eight regions are summarized in table $\mathrm{A}-1$. The table shows only equations in which each basin characteristic is significant at either the 1 or 5 percent level. For convenience of the users of this report, several equations were simplified and some complex variables were deleted at the sacrifice of some increase in the standard error. $Q_{10}$ can be used to determine design discharges at longer frequencies such as $Q_{25}$ and $Q_{50}$ by use of $Q_{25} / Q_{10}$ and $Q_{50} / Q_{10}$ ratios also summarized in table $A-1$.

Both the $Q_{50} / Q_{10}$ and $Q_{25} / Q_{10}$ ratios in table $A-1$ were determined from regional Erequency curves based on an analysis of the frequency curves for the individual gaging stations. Frequency curves based on short records are not necessarily reliable when extended to long return periods. However, the ratio defined by extending short-term records compared favorably with ratios defined by a few long-term records. These long-term records supplemented by short records were then used to define the peak ratios shown in table $A-1$ used in determination of $Q_{25}$ and $Q_{50}$. Noteworthy exceptions are the ratios for ephemeral and intermittent streams which are not well defined in any part of the state.

\section{Investigation of Other Characteristics}

A considerable reservoir of flow-characteristic and basincharacteristic data not published herewith were developed during the study. All of these data are available in the files of the 
Idaho district office of the U.S. Geological Survey and are discussed and summarized here briefly for reference purposes. Peak flow characteristics $Q_{1.11}, Q_{1} .25, Q_{2}$, and $Q_{5}, Q_{25}, Q_{50}$ and $Q_{100}$ were developed for each station using the modified log-Pearson Type III method. However, most of the figures developed for the longer frequencies are deficient because of the length of the extensions. $Q_{A}$ (the mean annual discharge) was determined for each gaging station having more than about 5 years of record. These flow characteristics were then regressed with the basin characteristics and regression equations were determined. In general, the standard error of estimate for peak discharges increased as the frequency departed from the 10-year return period.

Basin characteristics investigated but not used in the recommended regression equations are described in the appendix. Some of these characteristics are poorly defined, and deficiencies in some of them were noted. For example, quality of mapping is substandard for parts of the state and maps at $1: 250,000$ scale are the best available. Drainage area, elevation, forest, and several other basin characteristics cannot be accurately defined at this scale. Mean annual precipitation (P), 2-year-24-hour precipitation $\left(\mathrm{P}_{i}\right)$, and water yield (Y) are inadequately defined in mountainous areas and the figures may be poor for many basins used in the analysis. Soils index ( $S_{i}$, an index of the infiltration rate, is probably inadequately defined. Geologic factor $\left(G_{e}\right)$ is based on generalized geologic maps and probably is not an accurate measure of the ability of formations to transmit water to the stream. No doubt there are major deficiencies in other variables described in the appendix.

\section{RECOMMENDATIONS}

Floods in urbanized areas will become more of a problem as cities become larger. Monitoring of floods is recommended in urban areas such as Lewiston Orchards, Boise foothills, southwest Boise, Moscow, Pocatello, Idaho Falls, and other areas where extensive urban expansion is expected.

Flooding occurs along regulated streams during the nonirrigation season. Much of the flooding in southeastern Idaho in February 1962 and 1963 was along regulated streams that are entirely diverted during the summer months. Floods in many of these streams have been measured only once, and the magnitude and frequency are inadequately defined. Continuation of creststage gaging stations is needed at representative points in the southern part of the state. Measurements of unusual floods by indirect methods should be continued so that outstanding rates of flow and unit discharges may be documented. 
All of the streams significantly regulated by springs and large exchanges with ground water should be inventoried and measured. The channel reaches affected should be referenced on maps. This would assist in the design of hydraulic structures on these streams.

A study of the attenuation of flows in channels across deep alluvium and basaltic plains is needed. No basis for adjusting flood peaks as they move down channel from the mountains has been developed.

Changes in land use justify operation of crest-stage gages in some representative basins. Recently, thousands of acres of land per year have been converted from sagebrush to irrigated land or grassland. These areas are often denuded in winter. Floods of high magnitude result when the ground freezes and is covered with snow, followed by a quick snowmelt.

In the unforested, low-lying, arid, or semiarid valley and foothill areas of Idaho, recurrence intervals and runoff volumes of floods are relatively unknown. Hydrographs of thunderstorm or snowmelt floods are rare on ephemeral or intermittent streams draining these areas. Operation of a network of continuous-record gaging stations supplemented with precipitation gages is needed.

Boundaries of the regions shown in figure 1 are not well defined in several instances. Operation of crest gages near some of the boundaries would assist in regionalization.

Other methods of analysis may be more appropriate, especially in some areas of the state. Channel geometry studies show considerable promise but have not been investigated thoroughly in Idaho. A study of this type is now in progress in the White Clouds area of Idaho. The method is based on the principle that channel features adapt to accommodate the flow the channel has carried. The channel features can be measured at gaged sites and related to the flow characteristics for the gaging station. The relationships developed can then be applied to ungaged sites using channel geometry. A study of the relationships of channel geometry to flow characteristics should be initiated in Idaho.

Generally speaking, records on small streams are presently too short to define floods at recurrence intervals longer than about 20 years. This deficiency is especially acute in the unforested areas of the State where most streamflow is ephemeral or intermittent. A network of long-term records on low-altitude basins in the arid or semiarid sections of the state is recommended. 
Some accounts of large floods in Idaho date back to 1860 . This information is piecemeal and is scattered in historical diaries, old newspapers, personal notes, and, often, only in unwritten memoirs. Research and compilation of these data before many of the sources are lost would improve the data base for documenting the magnitude and frequency of floods at many sites. Geomorphic or botanical evidence of historic floods could also be investigated to improve the data base.

\section{STREAMFLOW INFORMATION \\ Sources of Information}

The U.S. Geological Survey publishes streamflow data for Idaho and is the major source of streamflow information. Each volume of the series of Geological Survey water-supply papers entitled "Surface Water Supply of the United States" contains a listing of the numbers of all water-supply papers in which records of surface-water data were published for the area covered by that volume. Each volume also contains a list of water-supply papers that give detailed information on major floods for the area.

Records through September 1950 for the State have been compiled and published in Water-Supply Papers 1314, 1316, and 1317; records for October 1950 to September 1960 have been compiled and published in Water-Supply Papers 1734, 1736, and 1737. These reports contain summaries of monthly and annual discharge or monthend storage for all previously published records, as well as some records not contained in the annual series of water-supply papers. The yearly summary table for each gaging station lists the numbers of the water-supply papers in which daily records were published for that station.

The new series of water-supply papers containing daily surface-water records for the 5-year period October 1, 1960, to September 30, 1965 (Water-Supply Papers 1927, 1933, and 1935) also contain lists of annual and special reports published as water-supply papers.

Records since October 1, 1965, are published in annual volumes entitled "Water Resources Data for Idaho."

Discharge measurements made at miscellaneous sites and peak discharges at partial-record stations are compiled for the period 1894-1967 in a special basic-data report "Miscellaneous Streamflow Measurements in Idaho, 1894-1967." 
Special reports on major floods or droughts or other hydrologic studies for the area have been issued in publications other than water-supply papers. Information relative to these reports may be obtained from the district office in Boise.

\section{Gaging-Station-Numbering System}

Each gaging station and partial-record station has been assigned a number in downstream order in accordance with the permanent numbering system used by the Geological Survey.

Numbers are assigned in a downstream direction along the main stream, and stations on tributaries between main-stream stations are numbered in the order they enter the main stream. A similar order is followed on other ranks of tributaries. The complete 8-digit number, such as 13038900 , includes the part number "13" plus a 6-digit station number. Miscellaneous measurement sites are designated by the letter "M" preceding the station number.

\section{SELECTED REFERENCES}

Benson, M. A., 1962, Factors influencing the occurrence of floods in a humid region of diverse terrain: U.S. Geol. Survey Water-Supply Paper 1580-B, 64 p. 1964, Factors influencing the occurrence of floods in the Southwest: U.S. Geol. Survey Water-Supply Paper 1580-D, $72 \mathrm{p}$.

Bodhaine, G. L., and Thomas, D. M., 1964, Magnitude and frequency of floods in the United States, part 12, Pacific Slope basins in Washington and upper Columbia River basin: U.S. Geol. Survey Water-Supply Paper 1687, $337 \mathrm{p}$.

Butler, Elmer, Reid, J. K., and Berwick, V. K., 1966, Magnitude and frequency of floods in the United States, part 10, The Great Basin: U.S. Geol. Survey Water-Supply Paper 1684, $256 \mathrm{p}$.

Dalrymple, Tate, 1964, Flood characteristics and flow determinations, sec. 25-I in Handbook of applied hydrology, edited by Ven Te Chow: New York, McGraw-Hill Book Co.

Decker, S. O., and others, 1970, Miscellaneous streamflow measurements in Idaho, 1894-1967: U.S. Geol. Survey basic-data report, $310 \mathrm{p}$.

Hazen, Allen, 1930, Flood flows: New York, John Wiley and Sons, $199 \mathrm{p}$.

Hoyt, W. G., and Langbein, W. B., 1955, Floods: N. J., Princeton Univ. Press, p. 59, 60, 72-76.

Leopold, L. B., 1968, Hydrology for urban land planning--a guidebook on the hydrologic effects of urban land use: U.S. Geol. Survey Circ. 554. 
Matthai, H. F., 1969, Floods of June 1965 in South Platte River basin, Colorado: U.S. Geol. Survey Water-Supply Paper 1850$B, 64 \mathrm{p}$.

Pacific Northwest River Basins Commission, 1970, Water Resources: Columbia-North Pacific Region Comprehensive Framework Study, app. V, V. 1, $543 \mathrm{p}$.

Rosa, J. M., 1968, Water-yield maps for Idaho: U.S. Agricultural Research Service, ARS 4l-14l, 15 p. 20 pl.

Ross, C. P., and Forrester, J. D., 1947, Geologic map of Idaho: U.S. Geol. Survey and Idaho Bur. Mines and Geology.

Thomas, C. A., and Harenberg, W. A., 1970, A proposed streamflowdata program for Idaho: U.S. Geol. Survey open-file report, $71 \mathrm{p}$.

Thomas, C. A., Broom, H. C., and Cummans, J. E., 1963, Magnitude and frequency of floods in the United States, part 13, Snake River basin: U.S. Geol. Survey Water-Supply Paper 1688, $250 \mathrm{p}$.

Thomas, D. M., and Benson, M. A., 1970, Generalization of streamflow characteristics from drainage-basin characteristics: U.S. Geol. Survey Water-Supply Paper 1975, $55 \mathrm{p}$.

U.S. Environmental Science Services Administration, 1970, 2-year 24-hour precipitation map of Idaho, annual: Special Studies Branch Office of Hydrology, Weather Bureau, annual.

Water Resources Council, 1967, A uniform technique for determining floodflow frequencies: Water Res. Council Bull. 15, $15 \mathrm{p}$. 
APPENDIX 


\section{Glossary}

Alluvium. A general term for all detrital deposits resulting

from the action of modern rivers, including sediments laid down in riverbeds, flood plains, lakes, and fans at the foot of mountain slopes.

Annual flood. The highest peak discharge in a water year. Anomalous areas. Those areas whose peak discharges depart considerably from the regional regression equations developed for this report.

Aquifer. A porous, water-bearing geologic formation or group of formations. Generally restricted to materials capable of yielding an appreciable supply of water.

Basalt. An extrusive, fine-grained, dark-colored igneous rock, often fractured or jointed in a columnar shape.

Base flow. See Base runoff.

Base runoff. Sustained or fair weather runoff. In most streams, base runoff is composed largely of ground-water discharge.

Cfs. See Cubic foot per second.

Cfsm. See Cubic feet per second per square mile. Concentration time. The period of time for storm runoff to flow from the most remote point of a catchment or drainage area to the outlet or point under consideration.

Correlation. See Regression.

Crest-stage gage. An installation at a particular site on a stream where periodic observations of gage height and discharge are obtained to determine the annual peak discharge. Peak data only is reported at these sites as opposed to a continuous record for a gaging station.

Cubic foot per second (cfs). The rate of discharge representing a volume of 1 cubic foot of water passing a given point during 1 second and is equivalent to 7.48 gallons per second or 448.8 gallons per minute.

Cubic feet per second per square mile (cfsm). The average number of cubic feet of water flowing per second from each square mile of area drained, assuming that the runoff is distributed uniformly in time and area.

Direct runoff. The runoff entering stream channels promptly after rainfall or snowmelt and that usually composes the bulk of the hydrograph of a flood.

Discharge. The rate of flow or volume of water and solids flowing in a stream at a given place and within a given period of time.

Diversion. The taking of water from a stream into a canal, pipe, or other conduit.

Drainage area. That area above a specified location on a stream measured on a horizontal plane, enclosed by a topographic divide from which direct surface runoff from precipitation normally drains by gravity into the stream above the specified point. 
Drainage basin. An area from which surface runoff is carried away by a single drainage system. Also called catchment area, watershed, drainage area.

Ephemeral stream. A stream that flows only in direct response to precipitation. Such a stream receives no water from springs and no long continued supply from melting snow or other surface source. Its channel is above the water table at all times. Also, the term may be arbitrarily restricted to streams or stretches of streams that do not flow continuously during periods of as much as 1 month.

Flood. A relatively high flow as measured by either gage height or discharge quantity, which usually overtops the natural or artificial banks in some reach.

Flood peak. The maximum rate of flow, usually expressed in cubic feet per second, that occurred during a flood.

Flood plain. That part of a river valley which is covered with water when the river overflows its banks at flood stages and which was built and is being reworked during flood stages under the channel conditions presently prevailing. This plain in most instances has been built up by stream-deposited alluvium.

Floodway. The channel of a river or stream and those parts of the flood plain adjoining the channel which are reasonably required to carry and discharge the floodwater or floodflow of the stream or river.

Frequency. The number of occurrences of a certain phenomenon in a given period of time.

Gage. See Gaging station and Crest-stage gage.

Gaging station. A particular site on a stream where systematic observations of gage height and discharge are obtained. The station usually has a recording gage for continuous measurement of the elevation of the water surface in the channel. Gaining stream. A stream or stretch of stream that receives water from ground water. The water surface of such a stream stands at a lower level than the water table of the ground-water body from which it receives water. Also called an effluent stream.

Ground-water runoff. That part of the runoff which has passed into the ground, has become ground water, and has been discharged into a stream channel as spring or seepage water. Also see Base runoff and Direct runoff.

Hydrograph. A graph showing the discharge of a stream with respect to time.

Indirect peak flow measurement. A determination of the peak discharge (other than by current meter) by the slope-area, contracted-opening, culvert, or flow-over-dam methods. An indirect measurement is usually based on a survey of highwater marks after a flood.

Infiltration. The flow or movement of water through the interstices or pores of a soil or other porous medium. The absorption of liquid by the soil as it falls as precipitation or from a stream flowing over the surface. 
Intermittent stream. A stream or reach of a stream that flows but part of the year when it receives water from springs or from surface flows during wet weather or from melting snow. Lacustrine deposits. Sedimentary deposits laid down underwater in the bed of a lake.

Lapse rate. The rate of temperature decrease per unit increase in elevation for a particular area.

Losing stream. A stream or stretch of stream that contributes water to the ground-water system. The water surface of such a stream stands at a higher level than the water table of the ground-water body to which it contributes water. Also called an influent stream.

Mean annual flood. The $Q_{2}$ flood or the annual flood which is exceeded, on the average, once in 2 years.

Multiple regression. See Regression.

Overland flow. The flow of rainwater or snowmelt over the land surface toward stream channels. After it enters a stream, it becomes runoff.

Perennial stream. A stream that flows continuously at all seasons of a year and during dry as well as wet years. Such a stream is usually fed by ground water, and its water surface generally stands at a lower level than that of the water table. Permeability. The capacity of a rock or rock material to transmit a fluid. Perviousness is sometimes used in the same sense as permeability.

Q10. I'he annual maximum peak flow that will be exceeded once every 10 years on the average (the 10-year flood).

Q25. The annual maximum peak flow that will be exceeded once every 25 years on the average (the 25-year flood).

Q50. The annual maximum peak flow that will be exceeded once every 50 years on the average (the 50-year flood).

Recurrence interval. The average interval of time within which a given flood will be exceeded once. Also known as return period.

Regression. The mathematical procedure of establishing a relation between a dependent variable and one or more independent variables. This procedure considers the frequency distribution of the dependent variable when the independent variable is held fixed at each of several levels. Regression is simple if there is only one independent variable and multiple if there is more than one independent variable. Regression is sometimes loosely but incorrectly referred to as correlation.

Regression equation. A predictive equation derived by methods of regression.

Regulated flow. Streamflow that has been subjected to regulation by reservoirs, diversions, or other manmade hydraulic controls.

Residual. A measure of the difference between the observed data value at a site and the value predicted by the regional regression equation. For the purpose of this report, it is the logarithm of the observed value minus the logarithm of 
the predicted value and thus is also in logarithmic form. The residual may be considered as a deviation from the regional norm.

Return flow. That part of irrigation water that is not consumed by evapotranspiration and that returns to the source stream or another body of water. Also known as return water. Return period. See Recurrence interval. Runoff. That part of the precipitation that appears in surface streams.

Significance. Determined by a statistical test of the hypothesis that a dependent variable is sufficiently explained by an independent variable at a certain predetermined level of significance $(0.01$ or 0.05$)$. The standardized "t" statistic for the associated degree of freedom of the independent variable was used for this test.

Standard error. Refers to the standard error of estimate of the dependent variable. This is actually the standard deviation of the regression line used to predict the dependent variable and has been converted from logarthmic units to an average percentage. Approximately two-thirds of the data values for the dependent variable are included within one standard error of the estimate made by the regression equation.

Stepbackward regression. A multiple regression technique that uses several independent variables in a regression and proceeds stepwise by deleting the least significant variable at the completion of each regression. The regression process is then repeated until only one independent variable remains. This type of regression results in several regression equations which are then tested for significance and the most useful equation is selected.

Stepforward regression. A multiple regression technique that tests all independent variables for significance with respect to the dependent variable and adds the most significant variable to the regression equation. The process is then repeated with the independent variables remaining and others are likewise added to the regression equation. The significance of each variable in the regression equation changes as each new variable is added, so all variables in the regression equation are again tested and may be dropped if deemed insignificant. This process continues until an optimum regression equation is derived with all variables significant at some predetermined confidence level.

Water table. The upper surface of the saturated zone of ground water except where that surface is formed by an impermeable formation. This surface is at atmospheric pressure.

Water year. A continuous 12-month period during which a complete annual cycle occurs, arbitrarily selected from the presentation of data relative to hydrologic or meteorologic phenomena. The U.S. Geological Survey uses the period October 1 to September 30 in the publication of streamflow records. 
Other Basin Characteristics Investigated in the Analyses

Basin characteristics investigated and not used in the final regional regression equations are described below.

Mean basin elevation (E), in thousands of feet above mean sea level, was measured on U.S. Geological Survey $1: 250,000$ scale maps or larger scale topographic maps of the U.S. Geological Survey, where available. Mean elevation was determined by laying a uniform grid over the map, determining the elevation at each grid intersection within the basin boundary, and averaging those elevations. The grid should be designed to give at least 40 intersections within the boundary.

Main channel length ( $L$ ), in miles, is the main stream-length from the gaging site to the basin divide, measured at intervals of one-fourth mile with dividers using U.S. Geological Survey 1:250,000 scale maps or maps of larger scale where practicable.

Main channel slope (S), in feet per mile, was determined from elevations at points 10 percent and 85 percent of the main channel length from the gaging site to the divide. This index is described by Benson (1962, 1964).

Orientation factor $\left(D_{f}\right)$ is a measure of the aspect or the direction in which the watershed faces. It was computed by the formula $D_{f}=2+\operatorname{CoS}\left(\theta-30^{\circ}\right)$, where $\theta$ is the direction of the downstream slope or the direction which the watershed faces in degrees clockwise from the south.

Soils index $\left(S_{i}\right)$ represents values of potential maximum infiltration, in inches, during an annual flood, under average soil moisture conditions. Values were computed for each basin from data provided by the soil Conservation Service.

Mean monthly temperature for January $\left(T_{1}\right)$, in degrees Fahrenheit, for the mean elevation of the basin, was determined on the basis of nearby weather records and lapse rates.

Mean monthly temperature for July $\left(T_{7}\right)$, in degrees Fahrenheit, was determined as for $\mathrm{T}_{1}$.

Corridor effect $\left(Z^{*}\right)$ is an index of the effect of the horizontal direction of the corridor into the basin. The corridor is defined as the route between the nearest major moisture source and the subject basin over which moisture-laden air can enter the basin with the least vertical rise. The corridor direction ( $Z$ ) is reckoned in degrees from the south. The corridor is arbitrarily assigned a constant width which spans the extremities of the basin. 
The major moisture sources are the lowlands of the Walla Walla Plateau, the Payette Section of the Columbia Plateau, and the Snake River Plain (see Fenneman, 1931). Only corridors with westerly components were used, so that corridor directions were all between zero and 180 degrees. Corridors were defined from 1:250,000 scale Army Map Service plastic relief maps. The corridor effect $Z^{*}$ was computed from the corridor direction, $Z$, by the formula $Z^{*}=2+\operatorname{Sin} Z$.

Runoff coefficient $\left(R_{C}\right)$ for the basin was computed by dividing water yield $(Y)$ by mean annual precipitation $(P)$, or $R_{C}=Y / P$.

Effective precipitation intensity $\left(P_{e}\right)$ was computed by multiplying the 2-year 24-hour precipitation $\left(\mathrm{P}_{i}\right)$ by the runoff coefficient $\left(R_{C}\right)$, or $P_{e}=P_{i} R_{C}$.

Potter's $T$ factor $\left(P_{t}\right)$ was computed by dividing channel length (L) by the square root of the main channel slope (S), or $P_{t}=L / \sqrt{\mathrm{S}}$.

Modified Potter's $T$ factor $\left(\mathrm{P}_{t \mathrm{~m}}\right)$ was computed by multiplying main channel length $(L)$ by length to centroid $\left(L_{C}\right)$ and dividing by square root of the slope, or $\mathrm{P}_{t m}=L L_{C} / \sqrt{S}$.

Snowmelt factor $\left(S_{n}\right)$ was computed from the following formula:

$$
S_{n}=\frac{\left(T_{7}-32\right)\left(D_{f}\right)}{(E)(F)(10-2)}
$$

where

$\mathrm{T}_{7}=$ Mean July temperature of the basin as defined previously.

$D_{f}=$ orientation factor of the basin as defined previously.

$\mathrm{E}=$ Mean elevation of the basin as defined previously.

$F=$ Forest cover as defined previously.

Snowmelt potential $\left(S_{p}\right)$ was computed by multiplying snowmelt factor $\left(S_{n}\right)$ by water yield $(Y)$, or $S_{p}=S_{n} Y$.

Corridor width (M) is the width of the corridor as described in "corridor effect" paragraph, measured in miles at right angles to the horizontal direction of the corridor.

2-year 24-hour precipitation $\left(\mathrm{P}_{i}\right)$ is the 24-hour precipitation, in inches which is exceeded, on the average, once in 2 years. The figure was determined from a map of 2-year 24-hour precipitation prepared by the U.S. Weather Bureau. The basin was outlined on the map and the inches of precipitation determined using the grid method (U.S. Environmental Science Services Administration, 1970). 
Mean annual precipitation (P) was determined by drawing the basin outline on maps showing precipitation for Idaho prepared by the Pacific Northwest River Basins Commission (1970). The average precipitation in the basin was then determined by the grid method.

Length to centroid $\left(L_{C}\right)$ was computed by determining the centroid for the basin area, and by measuring the shortest stream length from the gaging point to the centroid using dividers, as was done in computing stream length (L).

Geologic factor $\left(G_{e}\right)$ is an index of the ability of the geologic formation of a basin to transmit runoff to the stream. Each major formation in Idaho and adjacent areas were assigned a factor which expresses the relative impermeability of the formation. Dense rocks were given the largest number (95 for the highest.) and permeable alluvium or basalt was given the lowest ( 5 for the fractured Snake River basalts). Basins were outlined in the geologic map of Idaho. The percentage of each formation in the basin area was determined by the grid method, and a weighted geologic factor was computed.

The following three elevation parameters were computed by determining a weighted mean elevation of the highest ridges that collectively span the corridor at the appropriate points along the corridor.

Barrier elevation $\left(E_{b}\right)$ was determined at the highest ridge or series of ridges between a point 8 miles upwind from the basin and the lowland source of moisture, and was measured in thousands of feet.

Entry elevation $\left(E_{Y}\right)$ is the mean elevation along the upwind basin boundary in thousands of feet.

Exit elevation $\left(E_{X}\right)$ is the mean elevation along the downwind basin boundary in thousands of feet.

Approach (U), in thousands of feet, is an index of whether air masses are rising or falling in the corridor as they approach the basin. It was determined by subtracting the barrier elevation $\left(E_{b}\right)$ from the entry elevation $\left(E_{r}\right)$, and adding 5,000 feet to avoid negative numbers.

Entry (R), in thousands of feet, is an index of whether air masses rise or fall as they enter the basin, and was computed by subtracting the entry elevation $\left(E_{r}\right)$ from the mean elevation (E) and adding 5,000 feet.

Exit (X), in thousands of feet, is an index of whether air masses rise or fall as they leave the basin. It was determined 
by subtracting the mean elevation (E) from the exit elevation $\left(E_{\mathbf{X}}\right)$, and adding 5,000 feet.

Across (G) is an index of whether air masses rise or fall while crossing the entire length of the basin. It was measured in thousands of feet and was computed by subtracting the entry elevation $\left(E_{Y}\right)$ from the exit elevation $\left(E_{X}\right)$, and adding 5,000 feet.

Spillover (V) is an index of the percentage of the basin which is in a spillover area or the area of increased precipitation on the lee side as the incoming air masses enter the basin over a ridge. A spillover effect was assumed and computed only when the topography was such that there was a rise between the barrier elevation and the entry elevation, and a drop between the entry elevation and the mean elevation. The index was expressed as a percentage of the basin by multiplying the corridor width in miles by I mile, dividing by the basin area, and multiplying the quotient by 100. If no spillover or less than 1 percent was indicated, a figure of 1 was used to avoid zeros.

Intercept elevation $\left(E_{i}\right)$ is the elevation at which significant runoff begins on the basin or in the vicinity of the basin. That is, it is the elevation at which a runoff-elevation relationship for the basin would intercept 1 inch of runoff. It was determined from water-yield maps as the elevation nearest the 1-inch runoff line (Rosa, 1968).

Water yield $(Y)$ is the mean annual runoff of the basin in inches. It was determined from water-yield maps. The basin was outlined on the map, and the average yield was determined using the grid method (Rosa, 1968).

Spillover intensity $\left(V_{i}\right)$ for the basin was computed by multiplying spillover $(V)$ by corridor effect $\left(Z^{*}\right)$.

Elevation factor $\left(E_{f}\right)$ was computed by multiplying mean elevation (E) minus intercept elevation ( $\left.E_{i}\right)$ by intercept elevation $\left(E_{i}\right)$, or $E_{f}=\left(E-E_{i}\right) E_{i}$.

Water yield slope $\left(Y_{S}\right)$ for the basin was computed by subtracting 1 inch from the water yield, in inches, and dividing by the quantity of mean elevation minus intercept elevation, or $\mathrm{Y}_{\mathrm{S}}=(\mathrm{Y}-1) /\left(\mathrm{E}-\mathrm{E}_{\mathrm{i}}\right)$. 
Table A-1. Summary of regression equations by region for peak discharges in Idaho.

\begin{tabular}{|c|c|c|c|c|c|}
\hline Region & & $\begin{array}{l}\text { Regression } \\
\text { equation for } Q_{10}\end{array}$ & $\begin{array}{l}\text { Standard } \\
\text { error of } \\
\text { estimate } \\
\text { (percent) }\end{array}$ & $\begin{array}{l}\mathrm{Q}_{25} / \mathrm{Q}_{10} \\
\text { ratio }\end{array}$ & $\begin{array}{l}\mathrm{Q}_{50} / \mathrm{Q}_{10} \\
\text { ratio }\end{array}$ \\
\hline 1 & $Q_{10}=$ & $=49.8 \mathrm{~A}^{0.862}$ & 41 & 1.3 & 1.5 \\
\hline 2 & $Q_{10}=$ & $=66.5 \mathrm{~A}^{0.801_{\mathrm{F}}-0.236}$ & 61 & 1.3 & 1.5 \\
\hline 3 & $Q_{10}=$ & $=3.81 \mathrm{~A}^{0} 0.875 \mathrm{~F}-0.216 \mathrm{~N}^{2} .02$ & 51 & 1.3 & 1.5 \\
\hline 4 & $Q_{10}=$ & $=43.4 \mathrm{~A}^{0.857 \mathrm{~F}^{-0.210}}$ & 62 & 1.4 & 1.8 \\
\hline 5 & $Q_{10}=$ & $=13.0 \mathrm{~A}^{0.918}$ & 61 & 1.3 & 1.5 \\
\hline 6 & $Q_{10}=$ & $=188 \mathrm{~A}^{0.873} \mathrm{La}^{0.773} \mathrm{~N}^{-1.82}$ & 41 & 1.2 & 1.3 \\
\hline 7 & $Q_{10}=$ & $=20.6 \mathrm{~A}^{0} 0.806_{\mathrm{W}}-1.05$ & 59 & 1.2 & 1.4 \\
\hline 8 & $Q_{10}=$ & $=193 \mathrm{~A}^{0.758 \mathrm{~F}^{0}} 0.222 \mathrm{~N}^{-4.25}$ & 45 & 1.4 & 1.7 \\
\hline
\end{tabular}

EXPLANATION

$A=$ Drainage area in square miles.

$\mathrm{F}=$ Percentage of forest cover plus 1 percent.

La $=$ Percentage of area of lakes and ponds on the basin plus

1 percent.

$\mathrm{N}$ = Latitude of centroid of basin in degrees minus 40 degrees.

$\mathrm{W}$ = Longitude of centroid of basin in degrees minus 110 degrees. 


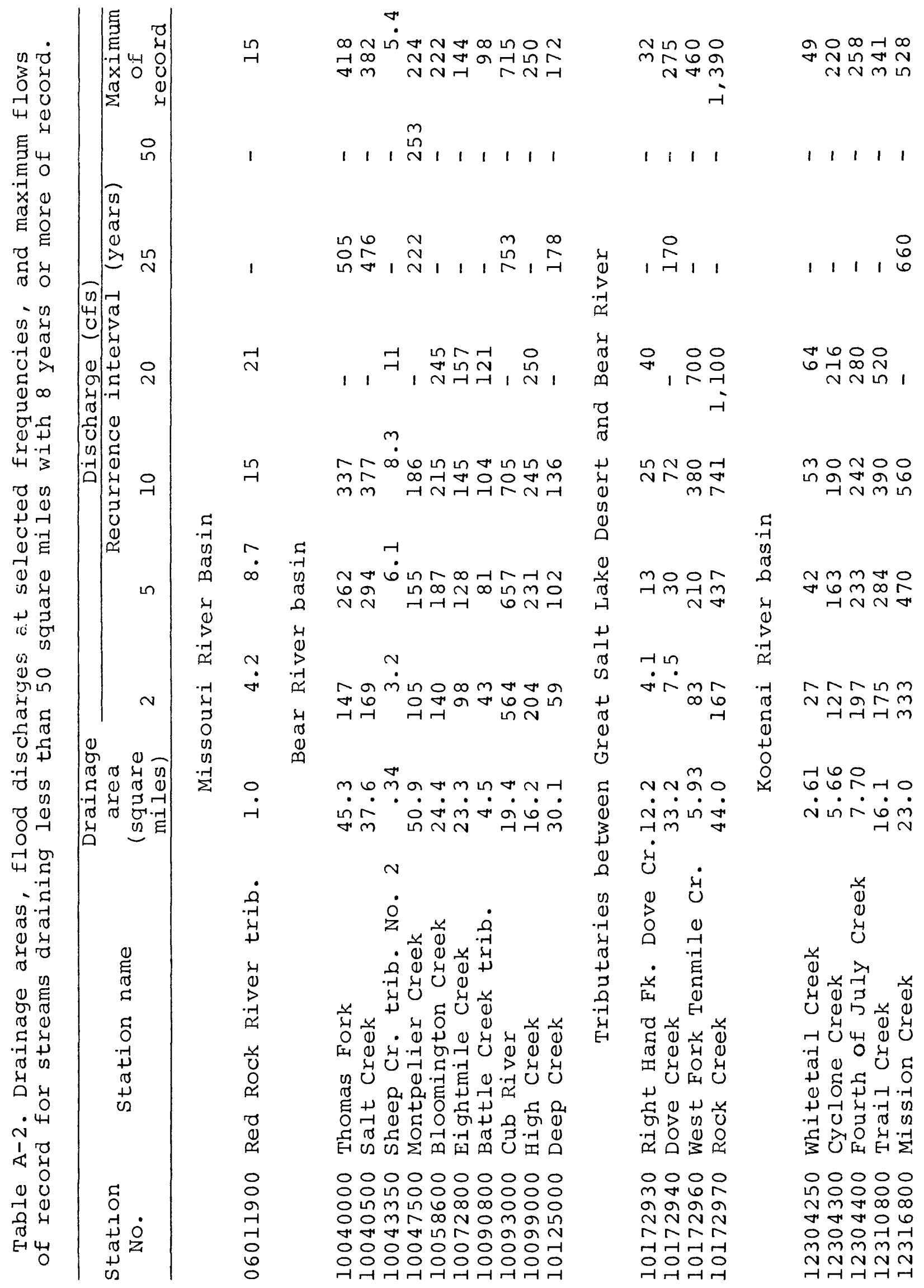



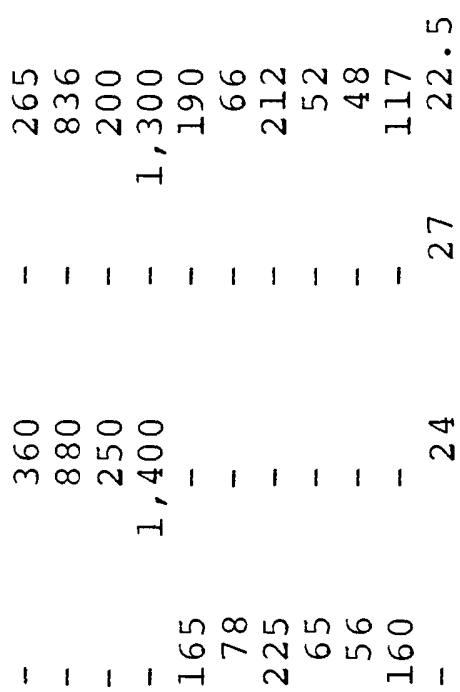

머ำ 을

$N \infty$ N $N$

$$
\text { ì }
$$

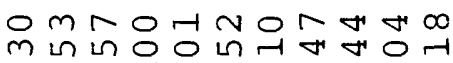
NNH的 n i

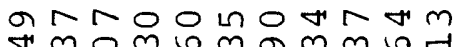
$\forall \mathrm{mom} 6 \mathrm{~m}$ \% $\mathrm{m}$. H. $\cdot \cdot \cdot \cdot \cdot \cdot \cdot \cdot \cdot \cdot$ $\dot{0} \dot{\omega} \dot{\infty} \dot{N} \dot{\sim} \dot{\sim} \dot{\sim} \dot{0}$ $\sim N{ }_{-1} N$<smiles>[Al][131In]</smiles><smiles>[TeH]</smiles><smiles>O</smiles>

4.

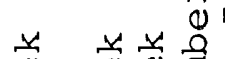

000000

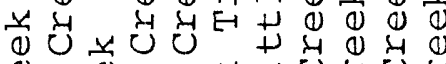

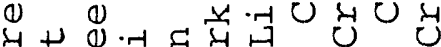

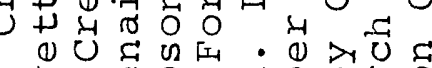

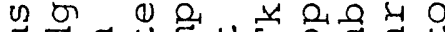
б

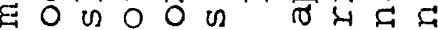

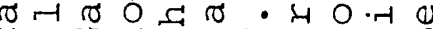

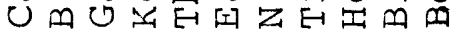

$\circ \circ 000000000$ $\infty$ in $\mathrm{N}$ in $\infty \mathrm{m}^{-1}-16 \mathrm{~m}$ nNOOmm rNNm

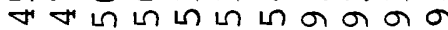
$m m m m m m m m m m$ N N N N N N N मन्नम

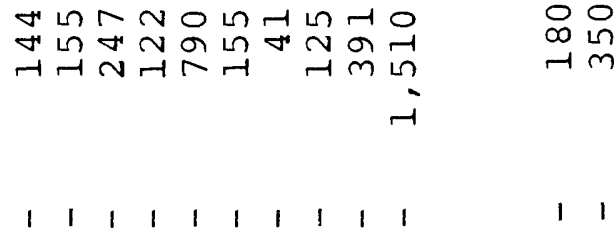

$1,1, \stackrel{0}{0}, 1 \stackrel{n}{ન}, 1, \quad$ 年

$\stackrel{\circ}{\rightarrow}$

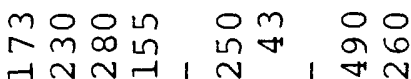

岸

$\rightarrow 1$

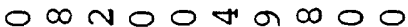

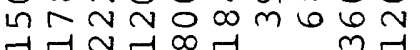

5
-1
0
0
0
4
0
0
0
-4
04
0
0
0
0
0
0
0
0

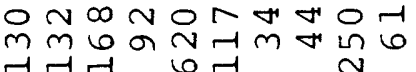

$\pi r$

$\infty 6$

$\neg-{ }^{-1}$ or $N$ N

rintronnga

ara ถरN

$m$

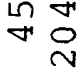

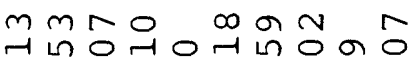

$\dot{m} \dot{\sim} \dot{\sim} \dot{\sim} \dot{\sim} \dot{\sim} \dot{\sim}$

$\begin{array}{cc}0 & \circ \\ + & m \\ 0 & \dot{m} \\ 0 & 0\end{array}$

$\begin{array}{cc}0 & \circ \\ + & m \\ 0 & \dot{m} \\ 0 & 0\end{array}$

$\begin{array}{cc}0 & \circ \\ + & m \\ 0 & \dot{m} \\ 0 & 0\end{array}$

×

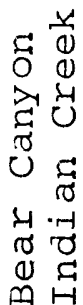

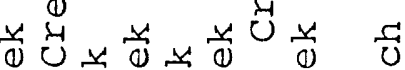

(1)

Uद्यु

\&

व का द्र 0 है $-1+4$ द्व द्व 0 उ

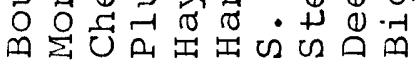

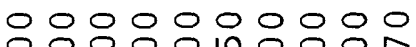
min $m \underset{r}{m}$ in

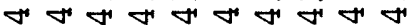

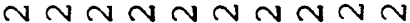

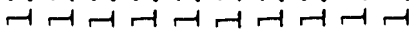

$\begin{array}{ll}n & 6 \\ - & 0\end{array}$

0
0
0
0
0
2
0
2
-1
$x$

है 


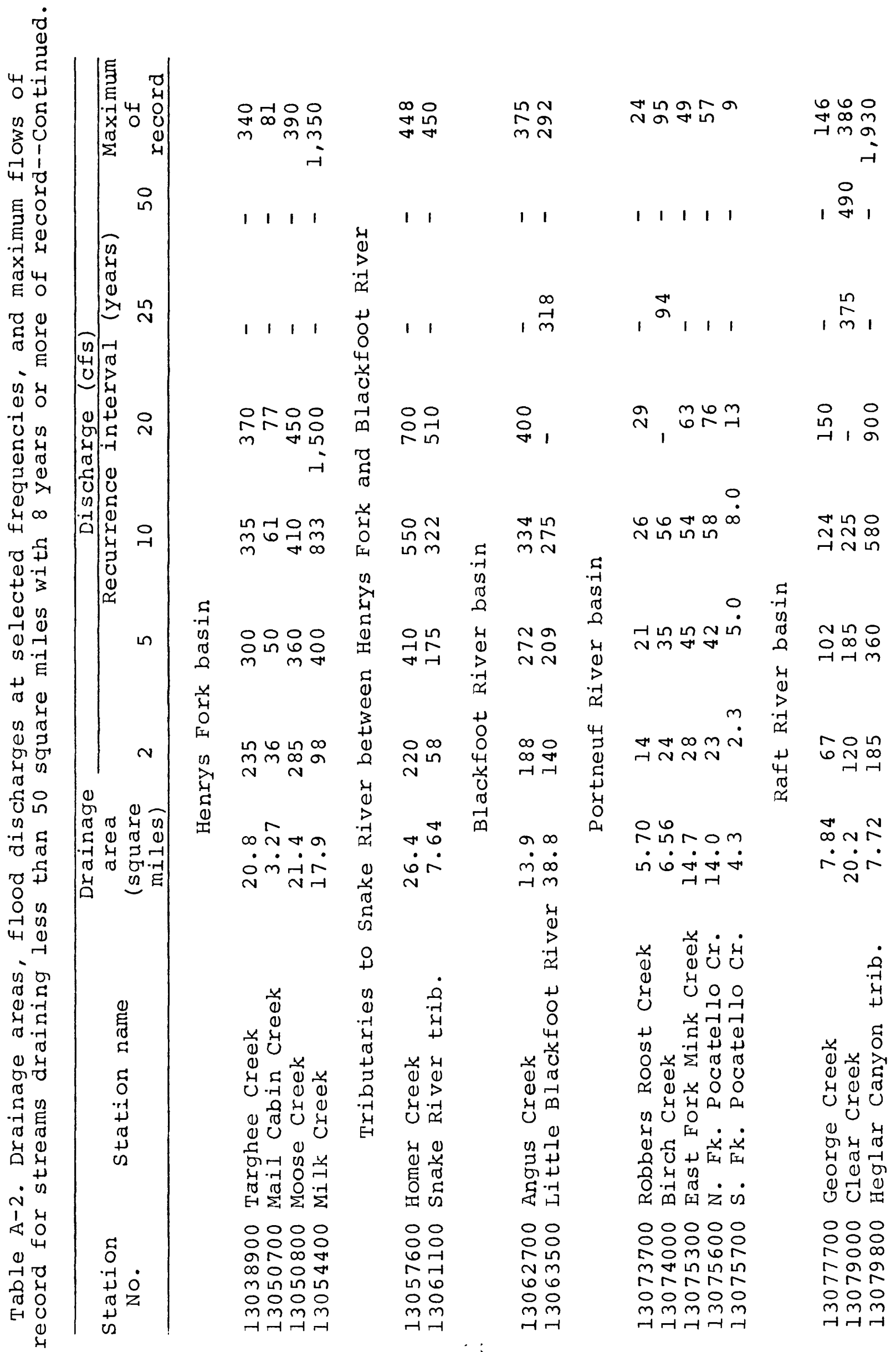




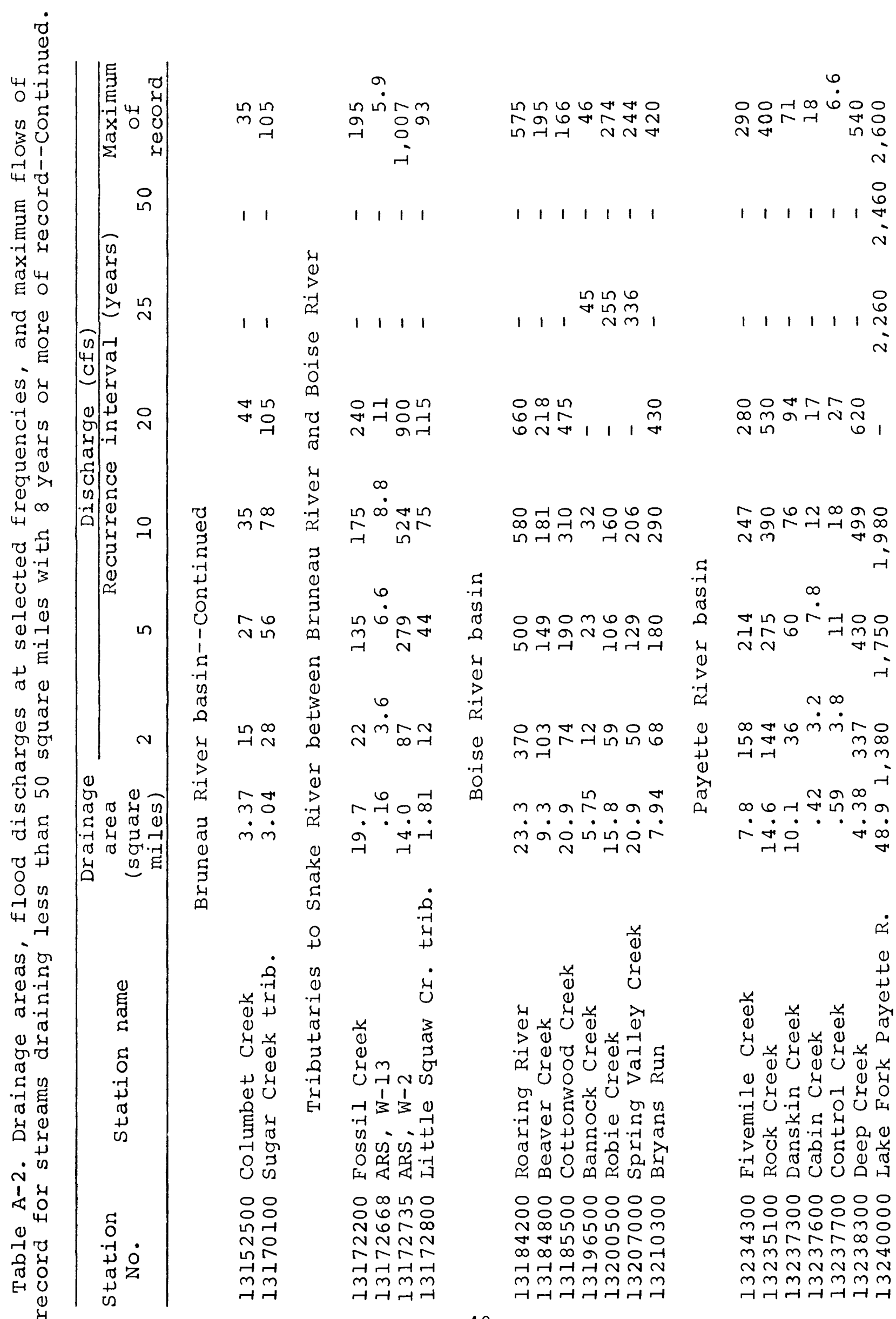




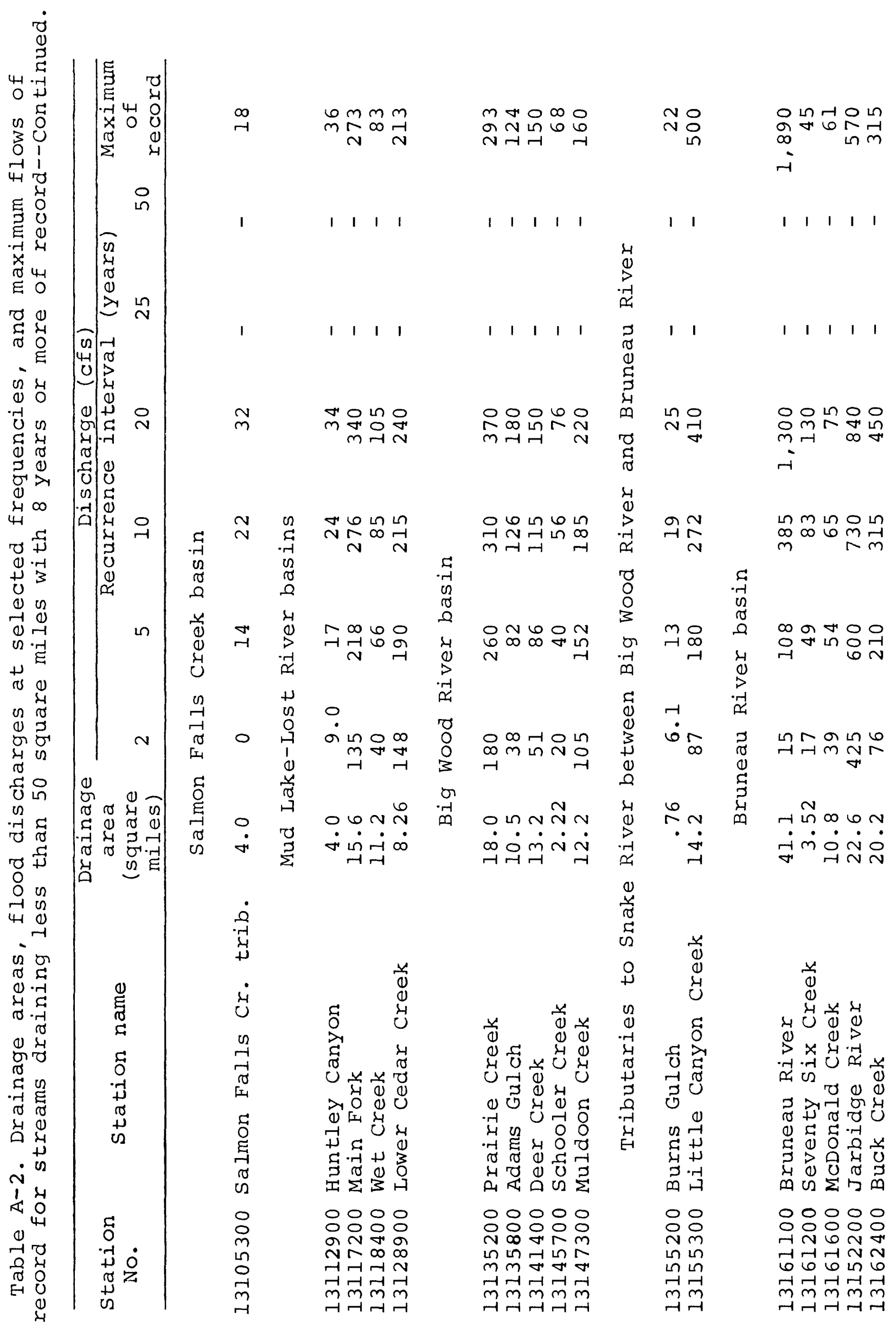




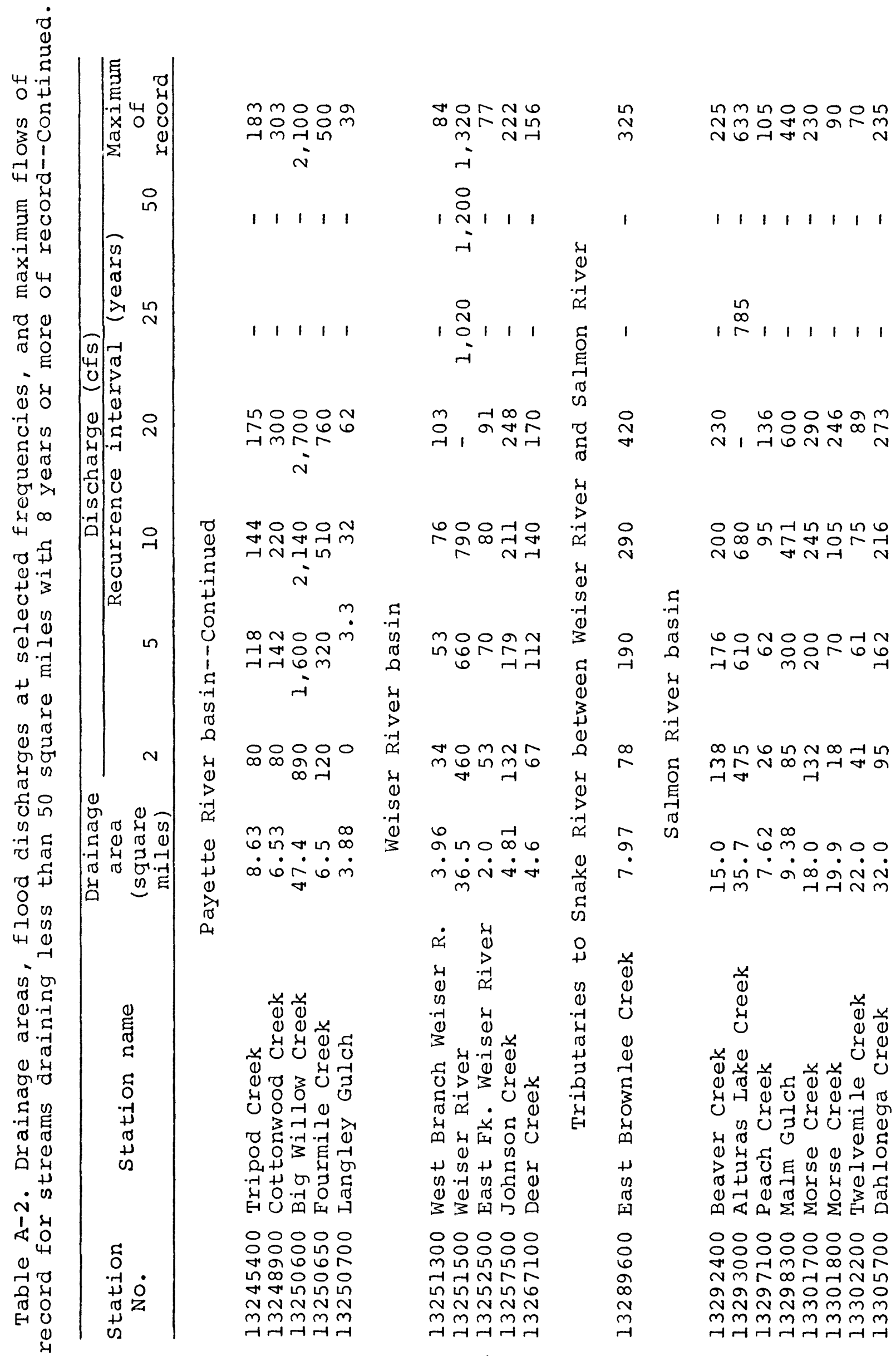




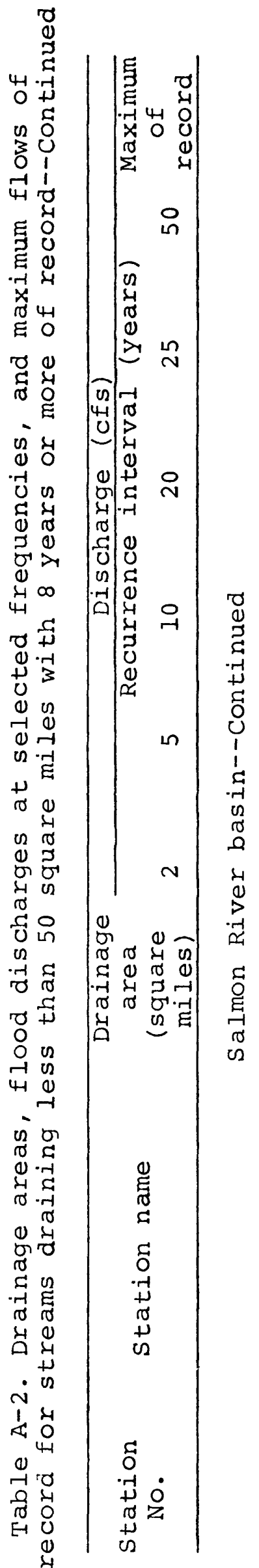

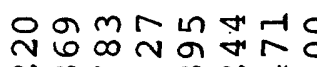

$\stackrel{1}{1}$

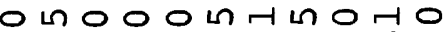
NMN $m \sim$

nNTO

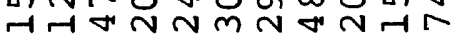

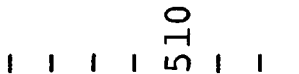

4
0
3
-4
14

$\infty \varnothing m$ in 0 $1 m N \stackrel{\infty}{i}$ i 1

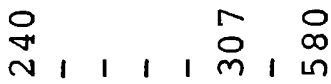

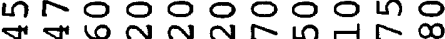

नम

$\infty \infty 000$ เ 00 तึ

11111111111

0

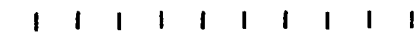

m

1

mNomo000

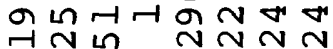

\begin{tabular}{l}
0 \\
\multicolumn{1}{c}{} \\
0 \\
4 \\
0 \\
0 \\
-4
\end{tabular}

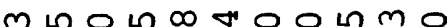

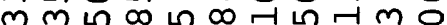
H<smiles>C1CCCCC1</smiles>

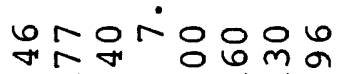

号

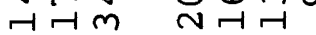

8

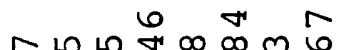

急

$\underset{\sim}{\sim}$

4
.4
0
0
0

ה R0

न

ن் $\dot{\sim} \dot{\sim} \dot{\sim} \dot{\sim} \dot{0}$

मी

(1)

म্

a

4)

mก O

$\infty \pi N$ व

कम $m$ ก

भा $N$ N

$\dot{0} \dot{\sim} \dot{\sigma} \dot{\nabla} \dot{m} \dot{0} \dot{\dot{m}} \dot{\vec{H}}$

$\infty$
0
0

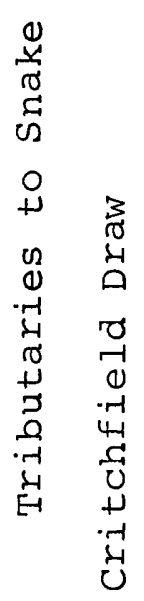

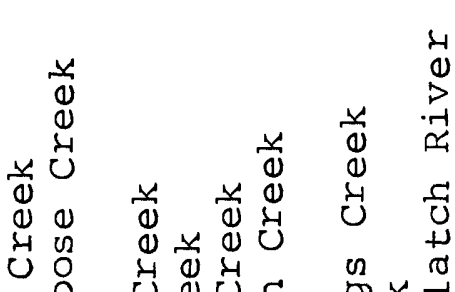

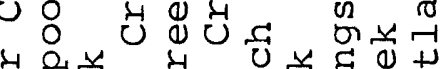
岑

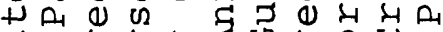

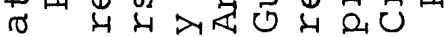

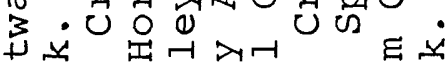

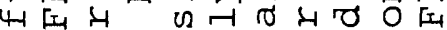

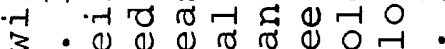
约

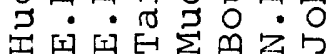

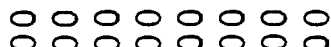

○ 00000000

in $-1 \mathrm{~m}$ in $06 \mathrm{~N}$

ㄷનનન નㅓન

$\mathrm{mm} m \mathrm{~mm} m$

$m m m m m m m$

નનમનનમનન

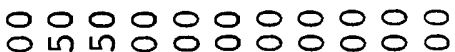
6 6 N N N $666 \pi N \infty$ क कानम $m m m m m m m m \nleftarrow \forall *$ $\mathrm{mmmmm} \mathrm{mm} \mathrm{mm}$ $\mathrm{mmmm} \mathrm{mm} \mathrm{m} \mathrm{m}$

ન્નમન્નન્નમન્ન 


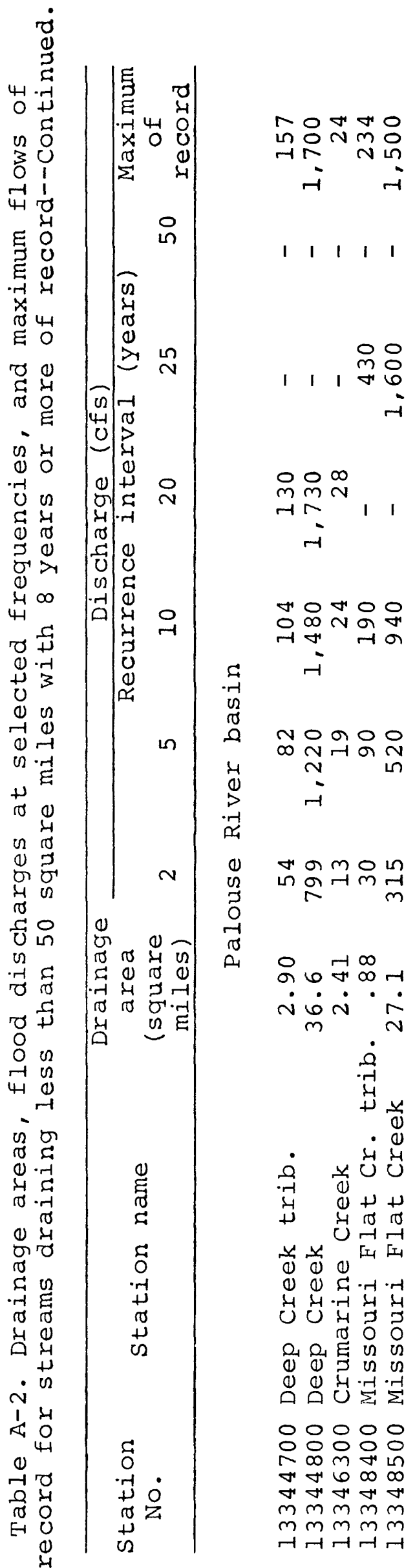


Table A-3. Maximum discharges at selected sites.

\begin{tabular}{|c|c|c|c|c|}
\hline $\begin{array}{c}\text { Station } \\
\text { No. }\end{array}$ & Stream name & $\begin{array}{c}\text { Drainage } \\
\text { area } \\
\text { (sq.mi.) }\end{array}$ & Date & $\begin{array}{l}\text { Dis- } \\
\text { charge } \\
\text { (cfs) }\end{array}$ \\
\hline
\end{tabular}

Bear River basin

\begin{tabular}{|c|c|c|c|c|}
\hline 10041000 & $\begin{array}{l}\text { Thomas Fork near Wyoming-Idaho } \\
\text { State line }\end{array}$ & 113 & $5-18-50$ & 869 \\
\hline 10047000 & Montpelier Cr. near llontpelier & $28 \cdot 2$ & $4-24-43$ & 224 \\
\hline 10071500 & Skinner Creek near Nounan & 5.41 & $6-8-44$ & 60 \\
\hline 10087500 & Mink Creek below Dry Fork & 19.3 & $5-29-48$ & 600 \\
\hline 110091030 & Battle Creek tributary No. & a2 & $8-2 I-6 I$ & 1,600 \\
\hline 10119000 & Little Malad River & 120 & $2-10-62$ & 450 \\
\hline 110120030 & Little Danish Canyon & 1.25 & $8-25-61$ & 1,170 \\
\hline 10091200 & Deep Creek near Clifton & 119 & $3-31-69$ & 152 \\
\hline 10120500 & Little Malad River & 223 & $2-11-62$ & 1,720 \\
\hline & Devil Creek & 15 & $2-1-63$ & 585 \\
\hline 1101729 & Deep Creek & a72 & $2-11-62$ & 1,220 \\
\hline
\end{tabular}

Tributaries to Great Basin between Great Salt Lake Desert and Bear River

M10172973 Rock Creek Ml0172974 Wood Canyon

$\begin{array}{lrr}93 & 2-10-62 & 1,630 \\ \text { a1.3 } & 2-10-62 & 29\end{array}$

Kootenai River basin

12305500 Boulder Creek

12309000 Cow Creek near Bonners Ferry

12311000 Deep Creek at Moravia

12311500 Snow Creek near Moravia

12312000 Caribou Creek near Moravia

12313000 Myrtle Creek near Bonners Ferry

12313500 Ball Creek near Bonners Ferry

i2315200 Rock Creek near Copeland

12315400 Trout Creek near Copeland

12317000 Mission Creek at Copeland

12317500 Brush Creek near Copeland

12319500 Parker Creek near Copeland

12320500 Long Canyon Creek near Porthill

12321000 Smith Creek near Porthill

12321500 Boundary Creek near Porthill

$\begin{array}{lrr}53 & 5-30-69 & 2,720 \\ 14.7 & 6-9-33 & 60 \\ 133 & 5-18-54 & 1,670 \\ 19.5 & 6-14-33 & 572 \\ 14.0 & 6-15-33 & 376 \\ \text { a37 } & 6-5-33 & 1,260 \\ \text { a27 } & 6-15-33 & 644 \\ 14.3 & 4-26-23 & 86 \\ \text { a20 } & 6-16-33 & 533 \\ \text { a31 } & 5-22-32 & 370 \\ \text { a7.2 } & 4-26-33 & 68 \\ 16.5 & 6-15-33 & 400 \\ \text { a29 } & 5-27-48 & 1,300 \\ \text { a70 } & 6-23-55 & 3,810 \\ \text { a97 } & 6-23-55 & 3,280 \\ & & \end{array}$

Pend Oreille River basin

M12392120 East Fork Creek

M12392150 Lightning Creek

12392300 Pack River

12392400 Rapid Lightning Creek

MI2392950 Indian Creek

$\begin{array}{rlr}20.4 & 6-8-64 & 903 \\ 90 & 5-27-48 b & 5,100 \\ 124 & 5-30-69 & 4,370 \\ 45 & 4-20-65 & 718 \\ 20 & 5-27-48 b & 800\end{array}$


Table A-3. Maximum discharges at selected sites--Continued.

\begin{tabular}{|c|c|c|c|c|}
\hline $\begin{array}{l}\text { Station } \\
\text { No. }\end{array}$ & stream name & $\begin{array}{c}\text { Drainage } \\
\text { area } \\
\text { (sq.mi.) }\end{array}$ & Date & $\begin{array}{l}\text { Dis- } \\
\text { charge } \\
\text { (cfs) }\end{array}$ \\
\hline
\end{tabular}

Spokane River basin

MI24l1800 East Fork Eagle Creek

M12411900 Cottonwood Creek

MI2413120 Canyon Creek

12413140 Placer Creek at Wallace

12413700 Latour Creek near Cataldo

MI2413450 Pine Creek

Ml24l3470 South Fork Coeur d'Alene River

MI2413900 St. Joe River

M12413950 North Fork St. Joe River

I2415000 St. Maries River

$\begin{array}{rrr}9.13 & 6-8-64 & 457 \\ 2.05 & 6-8-64 & 328 \\ 18.1 & 6-8-64 & 817 \\ 14.9 & 12-23-64 & a 1,300 \\ 24.8 & 2-19-68 & 1,400 \\ 74.0 & 12-23-64 & 5,290 \\ 310 & 2-21-61 & 9,440 \\ 472 & 5-29-48 & 13,400 \\ 111 & 5-28-48 & 3,500 \\ 437 & 12-22-33 & 23,800\end{array}$

Salt River basin

13025500 Crow Creek near Fairview, Wyo.

13026000 Stump Creek near Auburn, Wyo. 103

$4-19-46$

$5-18-48$

236

490

Tributaries to Snake River between Salt River and Henrys Fcrk

MI3034900 Snake River tributary No. 7

13035500 Pine Creek near Swan Valley

MI3037600 Birch Creek

MI3038410 Lyons Creek
$.236-1-63$
$63.25-16-36$
$21 \quad 2-11-62$
$2-11-62 b$
729
799
980
a 18
1,560

\section{Henrys Fork basin}

13041500 Sheridan Creek near Island Park

13047800 N. Fk. Squirrel Cr. near Squirrel

13051000 Trail Creek near Victor

13051500 Teton Creek near Driggs

13052500 Horseshoe Creek near Driggs

13053000 Packsaddle Creek near Tetonia

MI3054600 Canyon Creek

MI3-55320 Moody Creek

$\begin{array}{clr}82.1 & 5-3 I-38 & 447 \\ 2.40 & 5-16-64 & 184 \\ 47.6 & 6-7-52 & 445 \\ 33.8 & 6-6-52 & 1,030 \\ 11.7 & 5-3-52 & 8 I \\ 5.7 & 5-19-49 & 58 \\ \text { a } 76 & 2-1 I-62 \mathrm{~b} & 814 \\ \mathrm{a} 88 & 2-I I-62 \mathrm{~b} & 2,700\end{array}$

Willow Creek basin

13058000 Willow Creek

622

$2-11-62 \quad 5,080$

Tributaries to Snake River between Shelley and Blackfoot

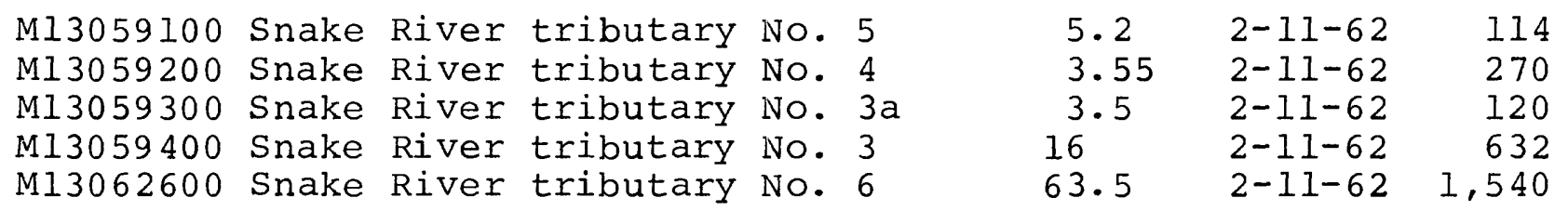


Table A-3. Maximum discharges at selected sites--Continued.

\begin{tabular}{|c|c|c|c|c|}
\hline $\begin{array}{l}\text { Station } \\
\text { No. }\end{array}$ & Stream name & $\begin{array}{c}\text { Drainage } \\
\text { area } \\
\text { (sq.mi.) }\end{array}$ & Date & $\begin{array}{l}\text { Dis- } \\
\text { charge } \\
\text { (cfs) }\end{array}$ \\
\hline
\end{tabular}

Blackfoot River basin

M13066600 Sand Creek tributary

Ml3066700 Black Canyon

M13066800 Henrys Creek

M13066900 Cedar Creek

$\begin{array}{lrr}\text { a } 9.8 & 2-11-62 & 1,210 \\ 7.29 & 8-9-63 & 1,940 \\ \text { a } 29 & 2-11-62 & 716 \\ 10.5 & 2-11-62 & 194\end{array}$

Portneuf River basin

13071500 Topons Creek near Chesterfield

M13072100 Portneuf River tributary

M13072300 Portneuf River

M13072750 Fish Creek

M13072900 Dempsey Creek

M13073100 Jenkins Canyon

M13073710 Green Canyon tributary

M13073720 Portneuf River

MI3073750 Marsh Creek

13074000 Birch Creek near Downey

M13075100 Rapid Creek

M13075400 Gibson Jack Creek

$\begin{array}{clr}45.7 & 5-21-12 & 355 \\ \operatorname{al} 30 & 2-1-63 & 574 \\ 332 & 2-11-62 \mathrm{~b} & 2,380 \\ 20.1 & 2-1-63 & 1,360 \\ 42 & 2-1-63 & 400 \\ 5.50 & 8-1-60 & 2,350 \\ 2.82 & 8-12-61 & 3,060 \\ 650 & 2-13-62 & 4,380 \\ \text { a68 } & 2-12-62 & 573 \\ 6.56 & 7-15-38 & 95 \\ 57.2 & 2-1-63 & 526 \\ 10.3 & 2-12-62 & 57\end{array}$

Bannock Creek basin

13076000 Bannock Creek

MI3076100 Rattlesnake Creek

M13076200 Bannock Creek
$227 \quad 12-24-64 \quad 7,790$

a77 2-11-62b 1,170

$413 \quad 2-11-62 \quad 4,010$

Rock Creek basin

Ml3077100 Trail Creek

M13077200 Rock Creek

MI3077400 Rock Creek

M13077550 Rock Creek

M13077630 Spring Canyon tributary

MI3077640 Rocky Hollow tributary

M13077650 Rock Creek

$\begin{array}{rrr}\operatorname{al1} & 9-9-61 & 487 \\ 96 & 2-11-62 & 1,770 \\ 156 & 2-1-63 & 5,100 \\ 216 & 2-11-62 & 2,120 \\ 6.77 & 8-18-61 & 152 \\ 2.26 & 5-30-63 & 498 \\ 320 & 12-23-64 & 7,950\end{array}$

Tributaries to Snake River between Rock Creek and Raft River

M13077652 Dairy Canyon

Ml3077655 Fall Creek
$26.2 \quad 1-17-71$

$14.27-10-70$ 
Table A-3. Maximum discharges at selected sites--Continued.

\begin{tabular}{lcc} 
Stream name & $\begin{array}{c}\text { Drainage } \\
\text { area } \\
\text { (sq.mi.) }\end{array}$ & Date $\begin{array}{c}\text { Dis- } \\
\text { charge } \\
\text { (cfs) }\end{array}$ \\
\hline
\end{tabular}

Raft River basin

13079070 Meadow Creek near Sublett

13079100 Cassia Creek above Stinson Creek

13079200

M13079750

M13079820

M13079890
Cassia Creek near Elba

Heglar Canyon

Heglar Canyon

Calder Creek

$\begin{array}{rr}37.7 & 5-9-71 \\ 7.2 & 6-24-69 \\ \mathrm{a} 84 & 12-23-64 \\ \mathrm{a} 45 & 2-11-62 \\ 62.0 & 1-17-71 \\ 23.6 & 1-17-71\end{array}$

982

153

471

735

Tributaries to Snake River between Raft River and Big Wood River

13082300 Marsh Creek near Albion

13083000 Trapper Creek near Oakley

MI 3084800 c "D" drain tributary

M13084900C "F" drain

13088500 Big Cottonwood Creek near Oakley

13092000 Rock Creek near Rock Creek

13108500 Camas Creek at Eighteenmile shearing corral

13113000 Beaver Creek at Spencer

13114000 Beaver Creek at Camas

13116000 Medicine Lodge Creek

13117000 Birch Creek near Reno

13117300 Sawmill Creek near Goldburg

13119000 Little Lost River near Howe

$13120000 \mathrm{~N}$. Fk. Big Lost R. at Wild Horse

13129800 Alder Creek below South Fork

13130900 Antelope Creek above Willow Creek

M13132540 Big Lost tributary

Ml3132555 Big Lost River tributary No. 2

Big Wood River basin

13135500 Big Wood River near Ketchum

13136500 Warm Springs Creek at Guyer Hot Springs

M13142850 Big Wood River tributary

Ml3145800 Thorn Creek

M13145900 Preacher Creek

M13147100 Dry Creek

13150500 Silver Creek

$\begin{array}{rrr}\text { a86 } & 1-17-71 & 828 \\ 53.7 & 8-17-41 & 270 \\ 5.0 & 12-23-64 & 86 \\ 64.7 & 12-23-64 & 2,990 \\ \text { a29 } & 5-30-12 & 125 \\ \text { a80 } & 5-19-70 & 461 \\ \text { a210 } & 5-8-69 & 2,590 \\ \text { a120 } & 4-24-69 & 642 \\ 510 & 4-21-62 & 229 \\ 165 & 4-15-62 & 361 \\ 320 & 4-1-62 & 220 \\ 74.3 & 6-12-65 & 651 \\ 703 & 8-11-36 & 450 \\ 114 & 6-12-65 & 1,420 \\ 27.6 & 5-24-67 & 165 \\ 93.4 & 5-24-67 & 829 \\ \text { a20 } & 2-11-62 & 190 \\ \text { a } 8.7 & 2-11-62 & 424\end{array}$

$137 \quad 5-24-67 \quad 1,690$

a96 $5-21-58 \quad 961$

$15.8 \quad 2-12-62 \quad 226$

$\begin{array}{lll}15.8 & 2-11-62 & 647\end{array}$

a26 12-23-64 2,210

a84 12-22-64d 8,050

a $88 \quad 2-4-63 \quad 757$ 
Table A-3. Maximum discharges at selected sites--Continued.

\begin{tabular}{|c|c|c|c|c|}
\hline No. & Stream name & $\begin{array}{c}\text { Drainage } \\
\text { area } \\
\text { (sq.mi.) }\end{array}$ & Date & $\begin{array}{l}\text { Dis- } \\
\text { charge } \\
\text { (cfs) }\end{array}$ \\
\hline
\end{tabular}

Clover Creek basin

$\begin{array}{rlrr}\text { M13153800 Clover Creek } & 71.2 & 12-23-64 & 7,000 \\ \text { M13153900 Calf Creek } & 39.4 & 12-23-64 & 6,400 \\ 13154000 & \text { Clover Creek near Bliss } & 140 & 2-13-70 \\ \text { M13154400 Clover Creek } & 265 & 12-23-6410,100\end{array}$

Tributaries to Snake River between Clover Creek and Bruneau River

13155000 King Hill Creek near King Hill

M13155100 Rosevear Gulch

13155400 Little Canyon Cr. at Berry Ranch

13156500 Bennett Creek near Bennett

13157000 Bennett Creek near Hammett

M13161050 Squaw Creek

$\begin{array}{rrr}78.9 & 2-1-63 & 2,320 \\ 55.9 & 8-31-63 & 1,160 \\ 26.9 & 12-23-64 & 1,330 \\ 21.3 & 4-2-43 & 204 \\ 68.6 & 2-16-13 & 550 \\ 61.5 & 9-16-61 & 368\end{array}$

Bruneau River basin

13163200 Sheep Creek

M13168380 Hot Creek

M13169250 Bruneau River tributary

13169500 Big Jacks Creek

13170000 Little Jacks Creek

M13170200 Sugar Creek

$\begin{array}{rrr}\operatorname{ar} 180 & 6-5-63 & 2,760 \\ 42.2 & 8-13-68 & 772 \\ .63 & 8-13-68 & 208 \\ 253 & 1-21-43 & 2,100 \\ 100 & 1-21-43 & 908 \\ 33.6 & 8-13-68 & 1,300\end{array}$

Tributaries to Snake River between Bruneau River and Boise River

\begin{tabular}{|c|c|c|c|c|}
\hline M13172100 & Browns Creek & a 31 & $8-13-68$ & 967 \\
\hline M13172300 & Sinker Creek & a74 & $12-23-64$ & 1,500 \\
\hline M13172600 & Rabbit Creek & a 45 & $6-19-62$ & 3,640 \\
\hline M13172620 & Rabbit Creek tributary & $4 \cdot 3$ & $6-19-62$ & 1,140 \\
\hline MI 3172640 & West Rabbit Creek & 27.0 & $6-20-62$ & 3,740 \\
\hline M1 3172700 & Nancy Gulch & a 4 & $6-19-62$ & 375 \\
\hline 13172720 & Macks Creek & 12.3 & $1-28-65$ & 390 \\
\hline 13172725 & Reynolds Creek tributary & .32 & $6-19-69$ & 50.7 \\
\hline 13172740 & Reynolds Creek & 90.2 & $12-23-64$ & 3,800 \\
\hline 13173500 & Sucker Creek & 413 & $2-1-63$ & 13,300 \\
\hline 13178000 & Jordan Creek & 440 & $12-24-64$ & 7,530 \\
\hline
\end{tabular}

Boise River basin

M13184950 Sheep Creek

13187000 Fall Creek

M13192400 Rattlesnake Creek

M13192900 Willow Creek

13198000 Elk Creek
$28.2 \quad 12-23-64 \quad 3,590$

$55.34-27-52 \quad 1,150$

$37.8 \quad 12-23-64 \quad 1,320$

$57.0 \quad 12-23-64 \quad 1,820$

$13.1 \quad 8-17-41 \quad 172$ 
Table A-3. Maximum discharges at selected sites--Continued.

\begin{tabular}{|c|c|c|c|c|}
\hline No. & Stream name & $\begin{array}{c}\text { Drainage } \\
\text { area } \\
\text { (sq.mi.) }\end{array}$ & Date & $\begin{array}{l}\text { Dis- } \\
\text { charge } \\
\text { (cfs) }\end{array}$ \\
\hline
\end{tabular}

Boise River basin--Continued

M13201400 Sheep Creek

Ml3203520 Highland Valley Gulch

Ml3203530 Highland Valley Gulch

M13203600 Maynard Gulch

M13203750 Squaw Creek

M13203800 Warm Springs Creek

M13204600 Orchard Gulch

M13204700 Picket Pin Creek

Ml3204800 Cottonwood Gulch

M13204900 Curlew Gulch

M13205650 Ussery Street Gulch

M13205700 Stuart Gulch

M13205750 Polecat Gulch

M13205800 Boise River tributary

M13205850 Pierce Gulch

M13206100 Seaman Gulch

M13207650 Goose Creek

$\begin{array}{rrr}0.40 & 8-20-59 & 210 \\ .39 & 8-20-59 & 2,100 \\ 1.69 & 8-20-59 & 3,370 \\ 2.25 & 8-20-59 & 9,540 \\ 1.47 & 8-20-59 & 7,320 \\ 3.84 & 8-20-59 & 9,390 \\ .73 & 8-20-59 & 1,500 \\ 2.50 & 8-20-59 & 7,720 \\ 12.0 & 8-20-59 & 1,580 \\ 3.95 & 8-20-59 & 2,300 \\ .06 & 6-21-67 & 90 \\ 9.04 & 1-29-65 & 412 \\ 1.01 & 6-21-67 & 210 \\ .25 & 6-21-67 & 9.8 \\ 1.18 & 6-21-67 & 12 \\ 1.76 & 6-21-67 & 12 \\ 1.42 & 5-20-68 & 195\end{array}$

Payette River basin

M13234215 Canyon Creek tributary

13234500 Clear Creek

13235500 Deadwood River

13236500 Deadwood River

iM13237820 Lightning Creek

M13237840 Scriver Creek

M13237900 Anderson Creek

13247000 Porter Creek

MI3248800 Shafer Creek

M13249050 Cottonwood Creek

M13249100 Little Squaw Creek

M13249200 Squaw Creek

Ml3250680 Big Willow Creek

Weiser River basin

13253000 East Fork Weiser River

13253500 Weiser River at Starkey

M13260100 West Fork Pine Creek

13255500 Hornet Creek near Council

13257000 Middle Fork Weiser River

13259500 Rush Creek

13260000 Pine Creek

13261000 Little Weiser River M13261600 Little Weiser River

$\begin{array}{rrr}a .25 & 7-9-68 & 1,550 \\ 59.6 & 5-31-43 & 754 \\ 10.4 & 6-15-52 & 354 \\ 112 & 5-26-28 & 2,150 \\ 24.4 & 12-23-64 & 864 \\ 27.3 & 12-22-55 & 406 \\ 34.0 & 12-22-55 & 690 \\ 21.2 & 8-11-41 & 181 \\ 74.6 & 12-22-55 & 1,240 \\ 29.6 & 12-22-55 & 722 \\ 75.3 & 12-22-55 & 1,000 \\ 345 & 12-22-64 & 12,000 \\ 138 & 1-15-56 & 1,640\end{array}$


Table A-3. Maximum discharges at selected sites--continued.

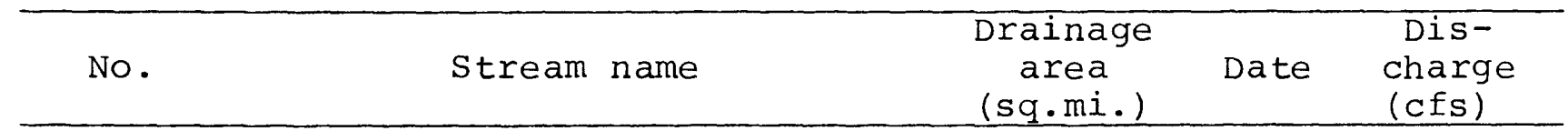

Weiser River basin--Continued

\begin{tabular}{|c|c|c|c|c|}
\hline M13261650 & Weiser River & 952 & $12-22-55$ & 16,600 \\
\hline M13263700 & Crane Creek & a 120 & $12-22-55$ & 4,120 \\
\hline M13263750 & Hog Creek & a25 & $12-22-55$ & 338 \\
\hline M13263800 & Mill Creek & alo & $12-22-55$ & 305 \\
\hline M1 3263950 & South Fork Crane Creek & a 52 & $1-17-70$ & 1,240 \\
\hline 13267000 & Mann Creek & a 56 & $3-27-40$ & 1,540 \\
\hline 13268500 & Monroe Creek & a 32 & $2-27-40$ & a 650 \\
\hline
\end{tabular}

Tributaries to Snake River between Weiser River and Salmon River

M13269230 Hog Creek

M13289650 Brownlee Creek

M13289900 Wildhorse Creek

M13289950 Wildhorse Creek

13290190 Pine Creek

$\begin{array}{rrr}22.5 & 1-17-70 & 681 \\ \text { a62 } & 12-22-55 & 159 \\ \text { a120 } & 12-22-55 & 2,550 \\ \text { a140 } & 12-22-55 & 2,990 \\ \text { a } 230 & 2-21-68 & 2,110\end{array}$

Salmon River basin

13292500 Salmon River

13295000 Valley Creek

13296000 Yankee Fork Salmon River

MI3297200 Slate Creek

13297300 Holman Creek

13297450 Little Boulder Creek

13299200 Challis Creek

13302000 Pahsimeroi River

13306000 North Fork Salmon River

13308500 Middle Fork Salmon River

13309000 Bear Valley Creek

13310000 Big Creek

l3310500 South Fork Salmon River

Ml3310700 South Fork Salmon River

13312000 East Fork South Fork Salmon River

13312500 Johnson Creek

13313000 Johnson Creek

Ml3313200 East Fork South Fork Salmon River

13313500 Secesh River

13314500 Warren Creek

M13315800 Little Salmon River

M13316200 Little Salmon River

M13316300 Indian Creek

M13316400 Rapid River

M13316450 Little Salmon River

$\begin{array}{rrr}94.7 & 5-29-52 & 721 \\ 147 & 5-24-56 & 2,000 \\ 195 & 6-12-21 & 3,360 \\ 228 & 8-9-63 & 1,580 \\ 6.10 & 6-13-65 & 225 \\ 18.4 & 6-25-71 & 279 \\ 91.2 & 6-12-65 & 918 \\ 845 & 6-8-57 & 796 \\ 214 & 6-13-33 & 901 \\ 138 & 5-24-56 & 2,980 \\ 180 & 5-27-56 & 3,860 \\ 470 & 6-3-48 & 5,800 \\ 92 & 5-27-56 & 1,620 \\ 324 & 5-28-48 & 5,200 \\ 104 & 6-14-33 & 2,050 \\ 54.7 & 5-27-48 & 1,510 \\ 213 & 5-27-56 & 5,440 \\ 424 & 5-28-48 & 10,400 \\ 104 & 6-3-48 & 2,500 \\ 37 & 6-3-48 & 1,100 \\ 189 & 6-1-48 & 3,300 \\ 345 & 12-22-55 & 4,480 \\ 2.66 & 5-20-70 & 34 \\ 122 & 5-29-48 & 1,600 \\ 550 & 6-1-48 & 9,200\end{array}$


Table A-3. Maximum discharges at selected sites--Continued.

No.

Stream name
Drainage
area

(sq.mi.)

Date charge

Dis-

(cfs)

Salmon River basin--Continued

M13316600 Slate Creek

M13317050 White Bird Creek

13317500 Deer Creek

$\begin{array}{crr}127 & 6-1-48 & 2,600 \\ \text { a96 } & 5-22-48 & 3,500 \\ 19.1 & 4-16-56 & 209\end{array}$

Tributaries to Snake River between Salmon River and Clearwater River

MI3335250 Snake River tributary No. 8

$1.0 \quad 6-8-64 \mathrm{e}$

622

Clearwater River basin

\begin{tabular}{|c|c|c|c|c|}
\hline M13335420 & Selway River & 211 & $5-28-48$ & 3,700 \\
\hline M13336620 & White Sand Creek & 244 & $5-29-48$ & 8,100 \\
\hline MI3336630 & Crooked Fork & 172 & $5-29-48$ & 5,700 \\
\hline 13336800 & Warm Springs Creek & 74.7 & $6-13-59$ & 2,260 \\
\hline 13336900 & Fish Creek & 89.2 & $5-20-64$ & 2,280 \\
\hline MI3337550 & South Fork Clearwater River & 434 & $5-29-48$ & 6,600 \\
\hline MI3338300 & Cottonwood Creek & 81.7 & $1-29-65$ & 1,740 \\
\hline MI3338950 & Lawyer Creek & 208 & $1-29-65$ & 2,460 \\
\hline 13339500 & Lolo Creek & 243 & $6-8-64$ & 3,430 \\
\hline M13340200 & North Fork Clearwater River & 201 & $5-28-48 b$ & 9,900 \\
\hline M13340400 & Kelly Creek & 380 & $5-28-48 b$ & 13,000 \\
\hline M13340800 & Little North Fork Clearwater R. & 414 & $5-29-48$ & 14,000 \\
\hline M13341140 & Big Canyon Creek & 225 & $1-29-65$ & 8,360 \\
\hline 13341500 & Potlatch River & 425 & $1-29-65$ & 16,000 \\
\hline MI3341800 & Lapwai Creek & 37.9 & $1-29-65$ & 2,190 \\
\hline 13342000 & Mission Creek & al6 & $1-29-65$ & $a 400$ \\
\hline M13342400 & Lapwai Creek & 235 & $1-29-65$ & 4,380 \\
\hline MI3343020 & Lindsay Creek tributary No. I & .10 & $7-16-64$ & 40.6 \\
\hline M13343040 & Lindsay Creek & .28 & $7-16-64$ & 176 \\
\hline M13343060 & Lindsay Creek tributary No. 3 & 4.25 & $7-16-64$ & 300 \\
\hline 13345000 & Palouse River & 317 & $1-\quad-48$ & 12,000 \\
\hline
\end{tabular}

a Approximately.

b Date may have been day following that indicated.

c Flood discharge may be affected by canals, drains, or other works of man.

d Date may have been 12-24-64.

e Date may have been 7-16-64. 
Table A-4. Gaging stations at which the $Q_{10}$ determined by the modified log-Pearson method differs by more than 70 percent from the Q10 determined by the regional equation.

\begin{tabular}{|c|c|c|c|}
\hline Region & $\begin{array}{l}\text { Station } \\
\text { No. }\end{array}$ & Station name & $\begin{array}{l}\text { Difference } \\
\text { (percent) }\end{array}$ \\
\hline 2 & 13302200 & Twelvemile Creek near Salmon & -72 \\
\hline 2 & 13336100 & Meadow Creek near Lowell & 206 \\
\hline 2 & 13348400 & $\begin{array}{l}\text { Missouri Flat Creek tributary } \\
\text { near Pullman, Wash. }\end{array}$ & 208 \\
\hline 3 & 13154000 & Clover Creek near Bliss & 97 \\
\hline 3 & 13155000 & King $\mathrm{Hill}$ Creek near King Hill & 142 \\
\hline 3 & 13238300 & Deep Creek near McCall & 203 \\
\hline 3 & 13240000 & $\begin{array}{l}\text { Lake Fork above Jumbo Creek, } \\
\text { near McCall }\end{array}$ & 80 \\
\hline 3 & 13240500 & $\begin{array}{l}\text { Lake Fork above reservoir, } \\
\text { near McCall }\end{array}$ & 75 \\
\hline 3 & 13249000 & Squaw Creek near Gross & 214 \\
\hline 3 & 13290150 & $\begin{array}{l}\text { North Fork Pine Creek near } \\
\text { Homestead, Oreg. }\end{array}$ & 218 \\
\hline 3 & 13335200 & $\begin{array}{l}\text { Critchfield Draw near Clarkston, } \\
\text { Wash. }\end{array}$ & 156 \\
\hline 4 & 13172680 & Reynolds Creek station W4 & 143 \\
\hline 4 & 13172725 & Reynolds Creek station W12 & 323 \\
\hline 4 & 13172730 & Reynolds Creek station W11 & 121 \\
\hline 4 & 13172740 & Reynolds Creek station WI & 135 \\
\hline 4 & 13235100 & Rock Creek at Lowman & 137 \\
\hline 5 & 13293000 & Alturas Lake Creek near Obsidian & 96 \\
\hline 5 & 13297300 & Holman Creek near Clayton & -75 \\
\hline 5 & 13298300 & Malm Gulch near Clayton & 364 \\
\hline 6 & 13027200 & Bear Canyon near Freedom & 130 \\
\hline 6 & 13057600 & Homer Creek near Herman & 85 \\
\hline 7 & 13075700 & $\begin{array}{l}\text { South Fork Pocatello Creek } \\
\text { near Pocatello }\end{array}$ & -70 \\
\hline 7 & 10084500 & Cottonwood Creek near Cleveland & 122 \\
\hline 7 & 10090800 & $\begin{array}{l}\text { Battle creek tributary near } \\
\text { Treasureton }\end{array}$ & 164 \\
\hline 7 & 10096500 & Maple Creek near Franklin & 98 \\
\hline 7 & 10099000 & High Creek near Richmond & 120 \\
\hline 7 & 13062700 & Angus Creek near Henry & 262 \\
\hline 8 & 13161300 & Meadow Creek near Rockland, Nev. & 106 \\
\hline 8 & 13162200 & Jarbidge River at Jarbidge, Nev. & 120 \\
\hline
\end{tabular}




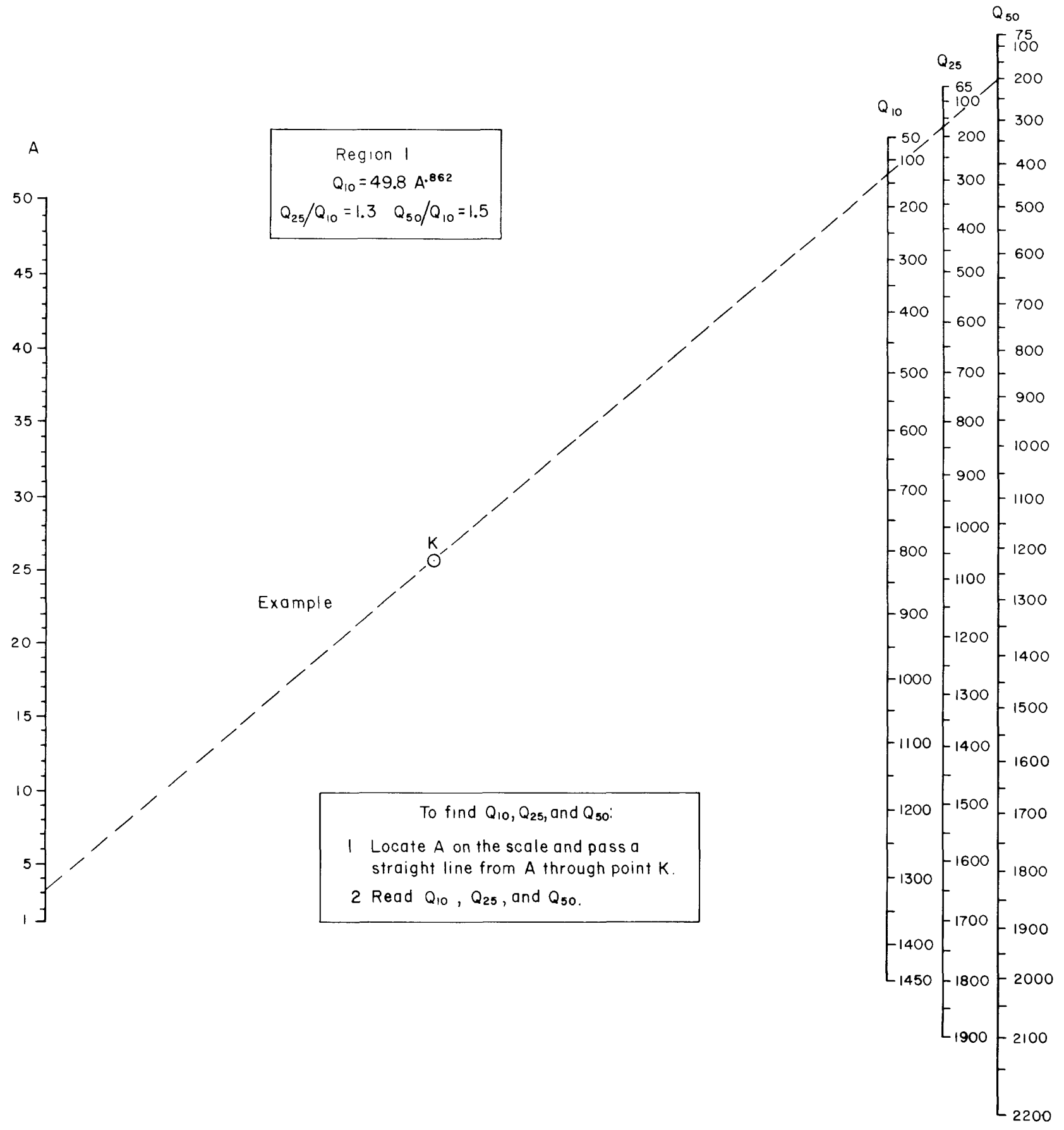




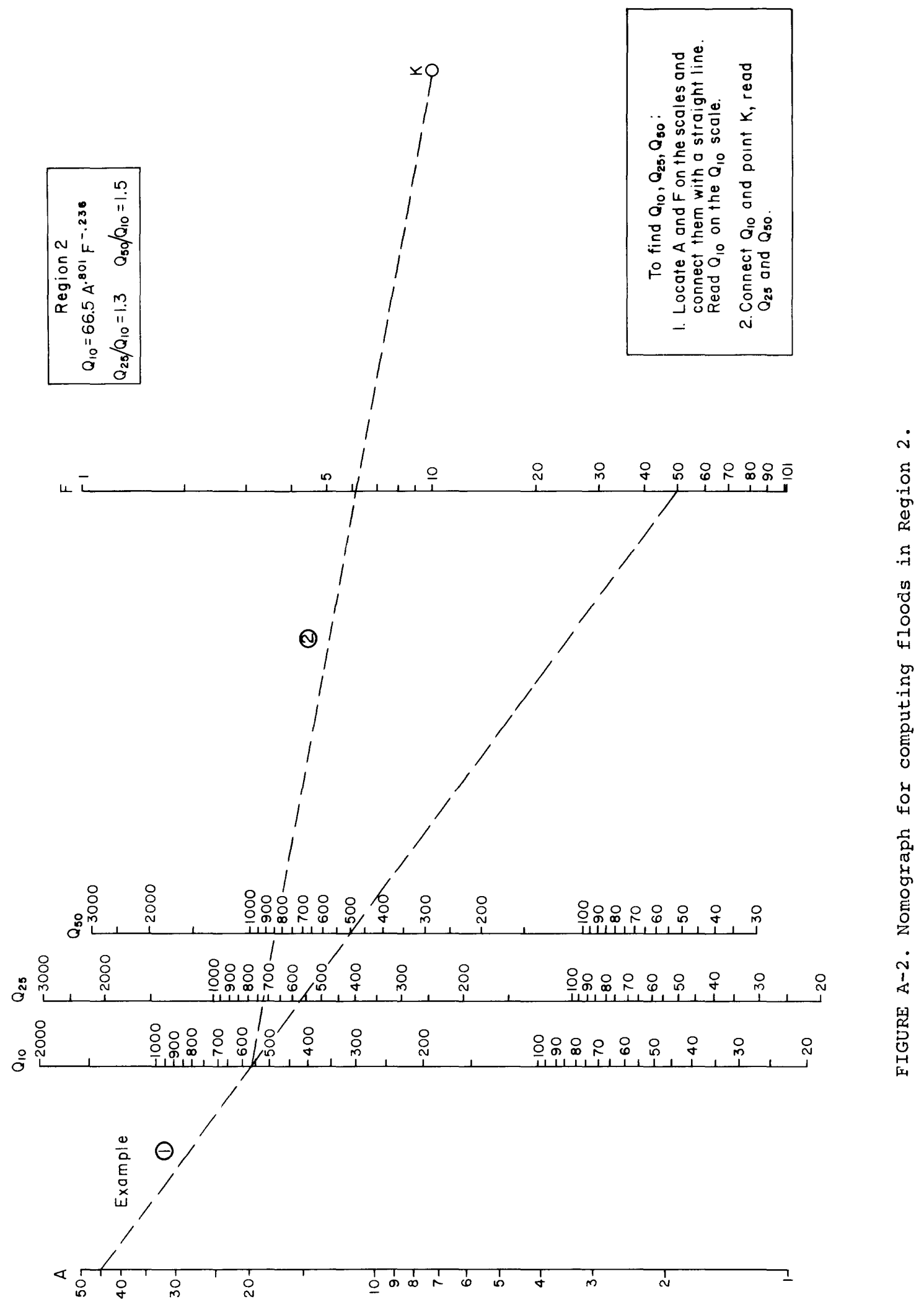




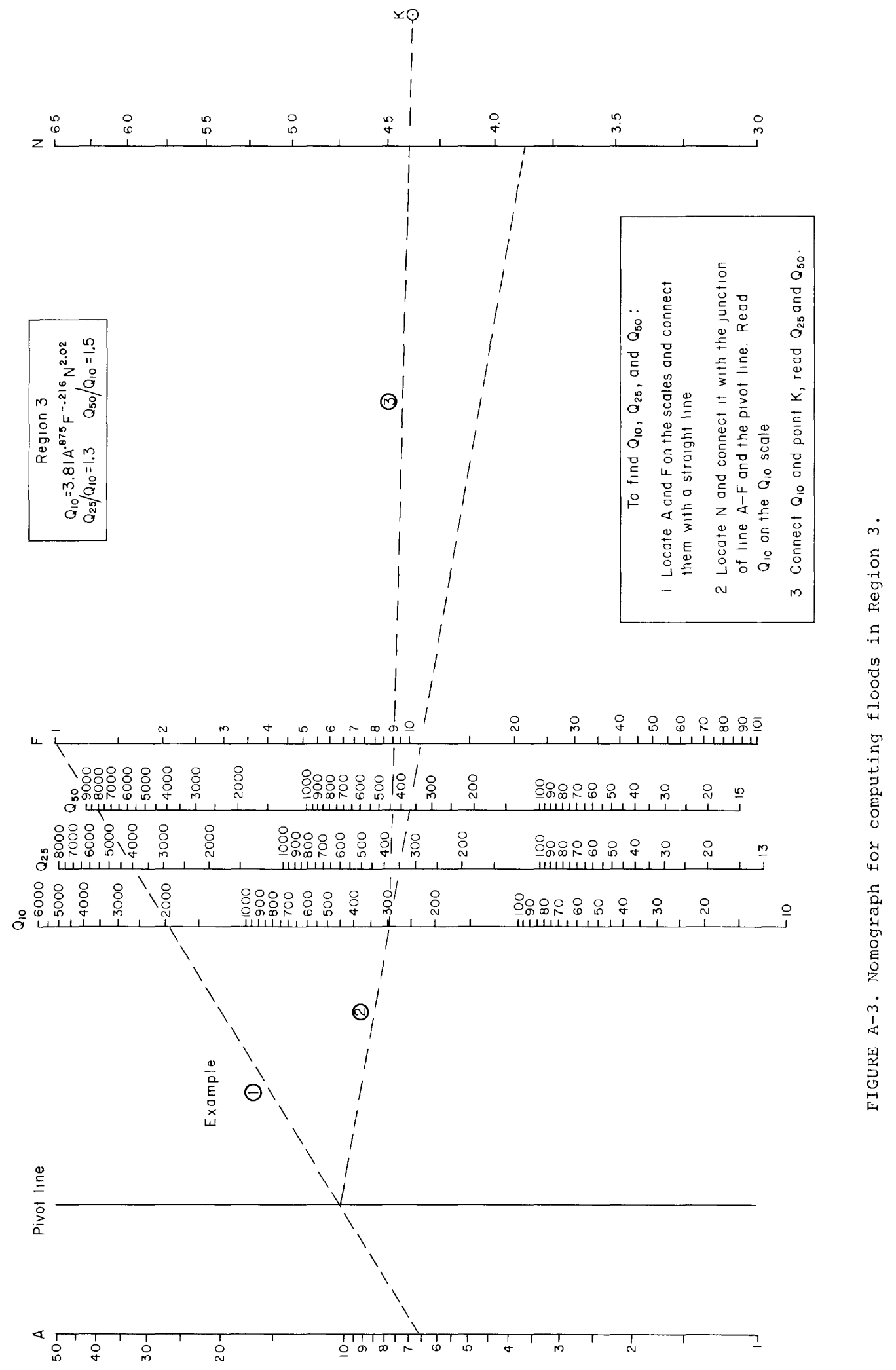




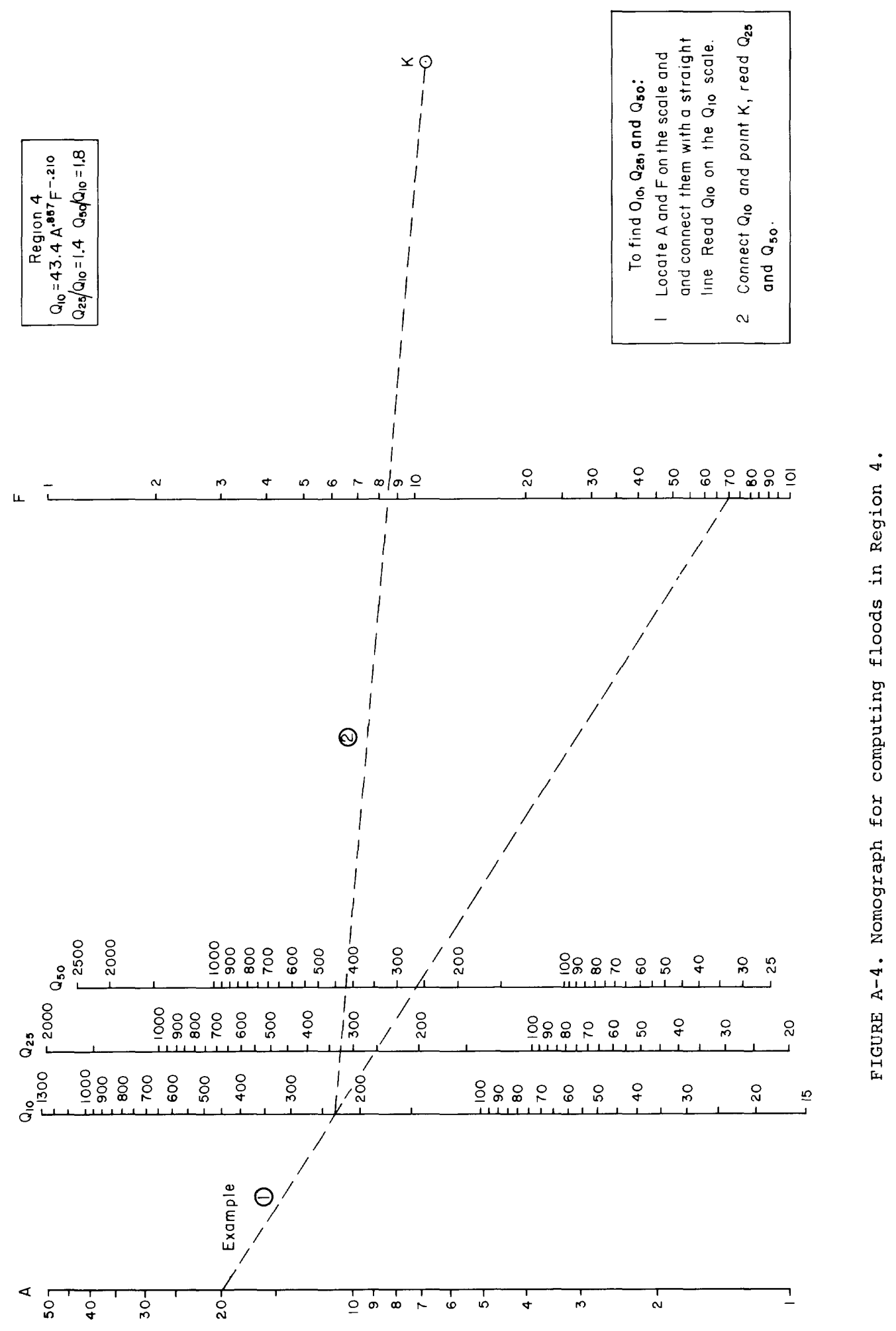




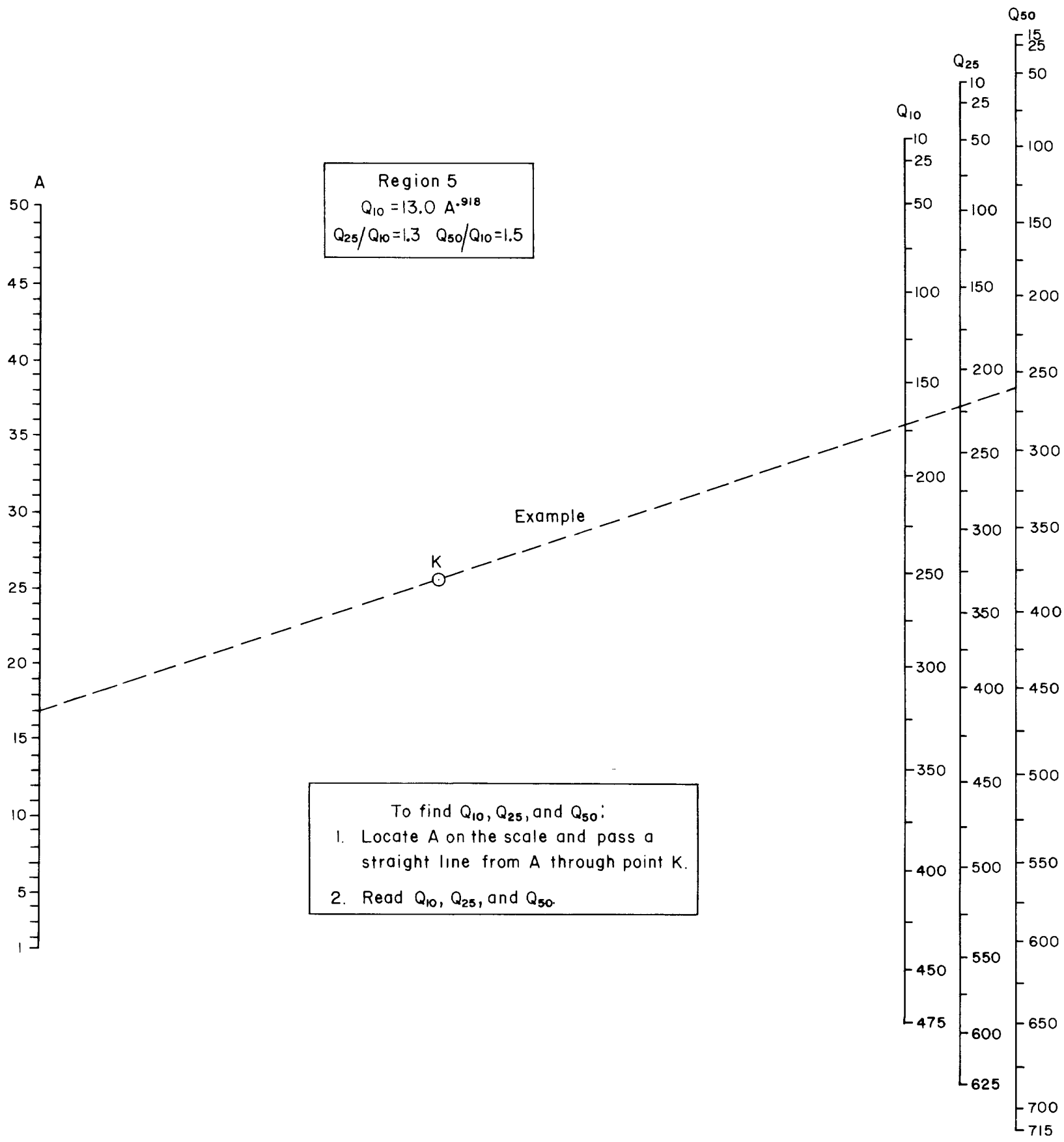

FIGURE A-5. Nomograph for computing floods in Region 5. 


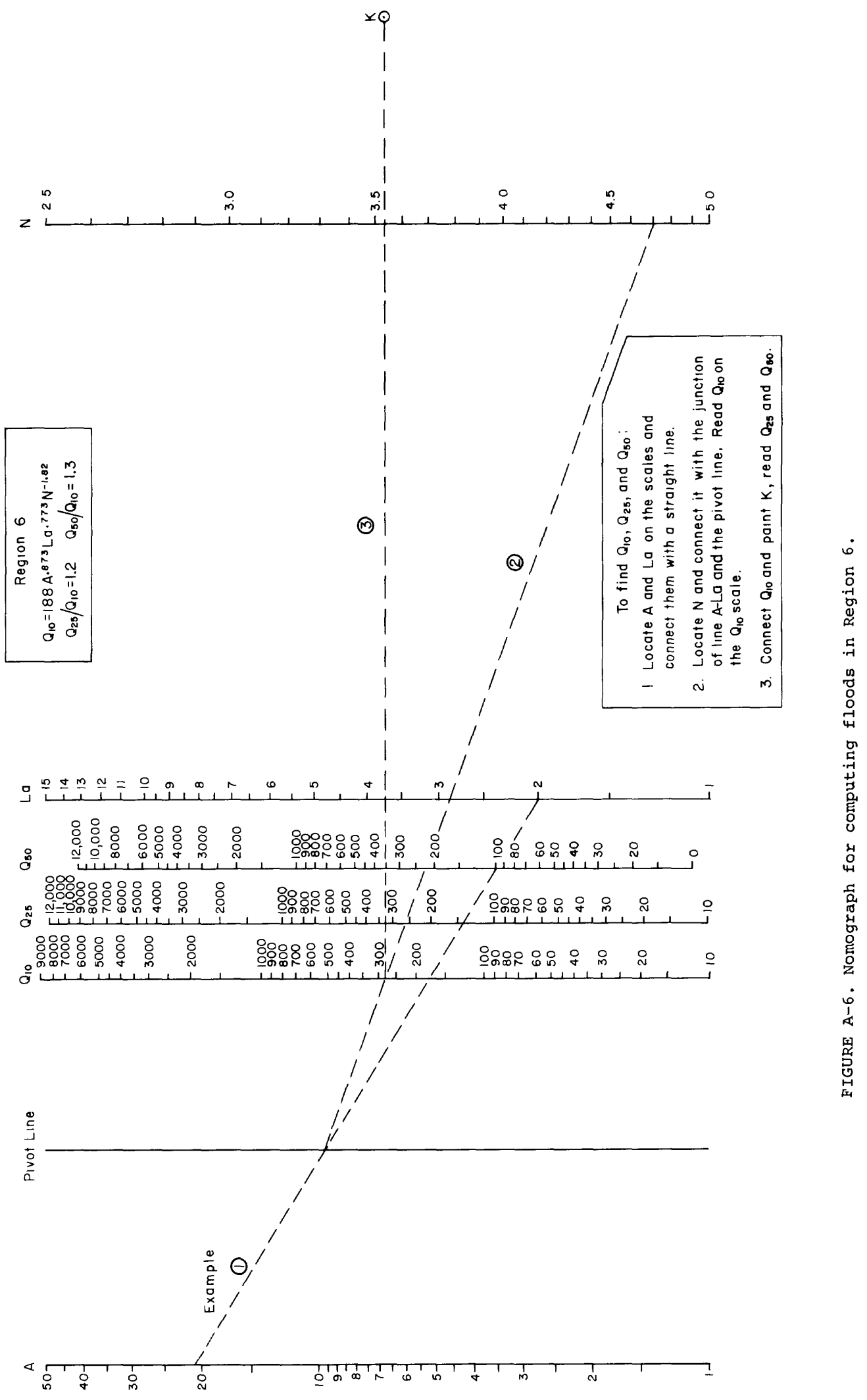




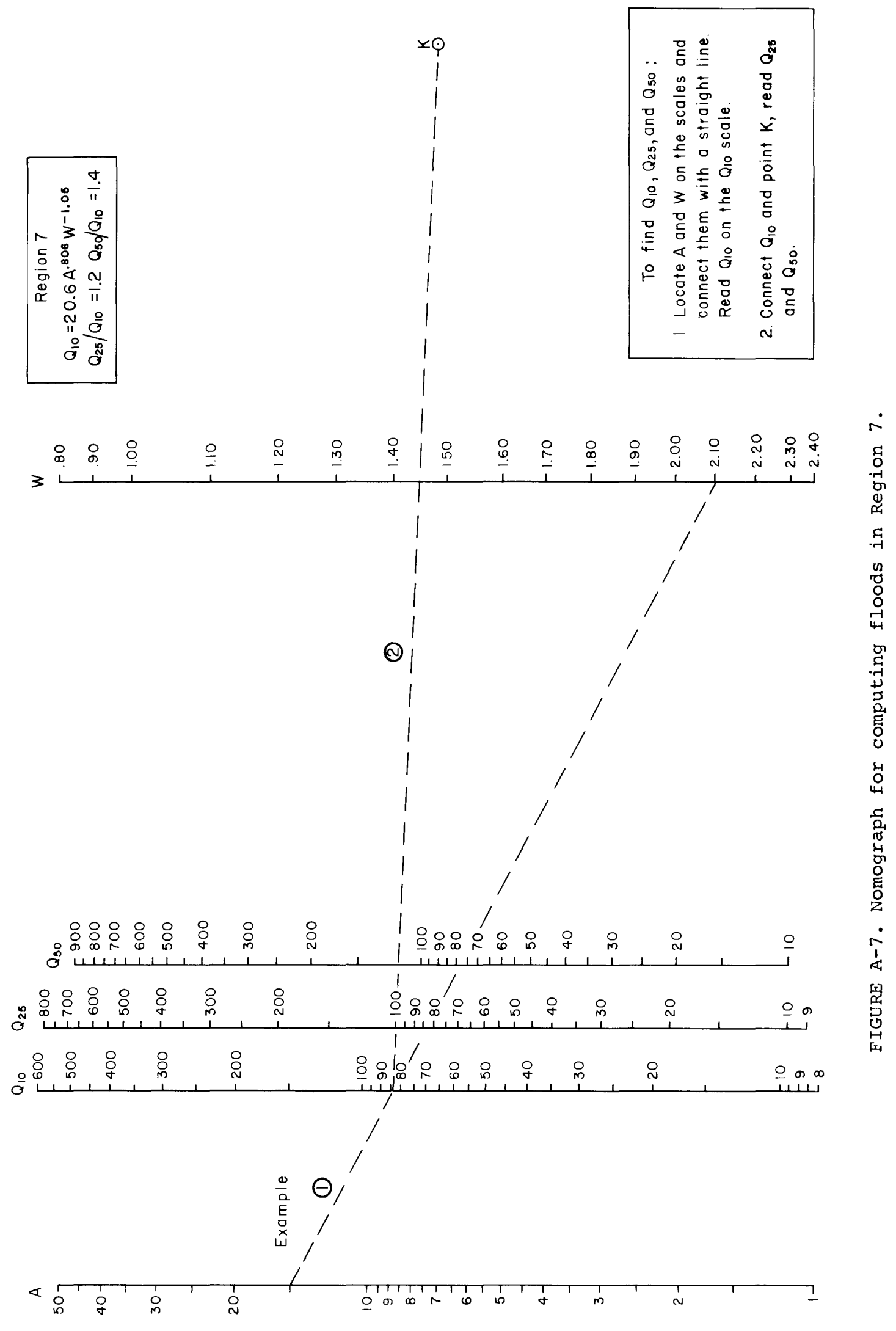




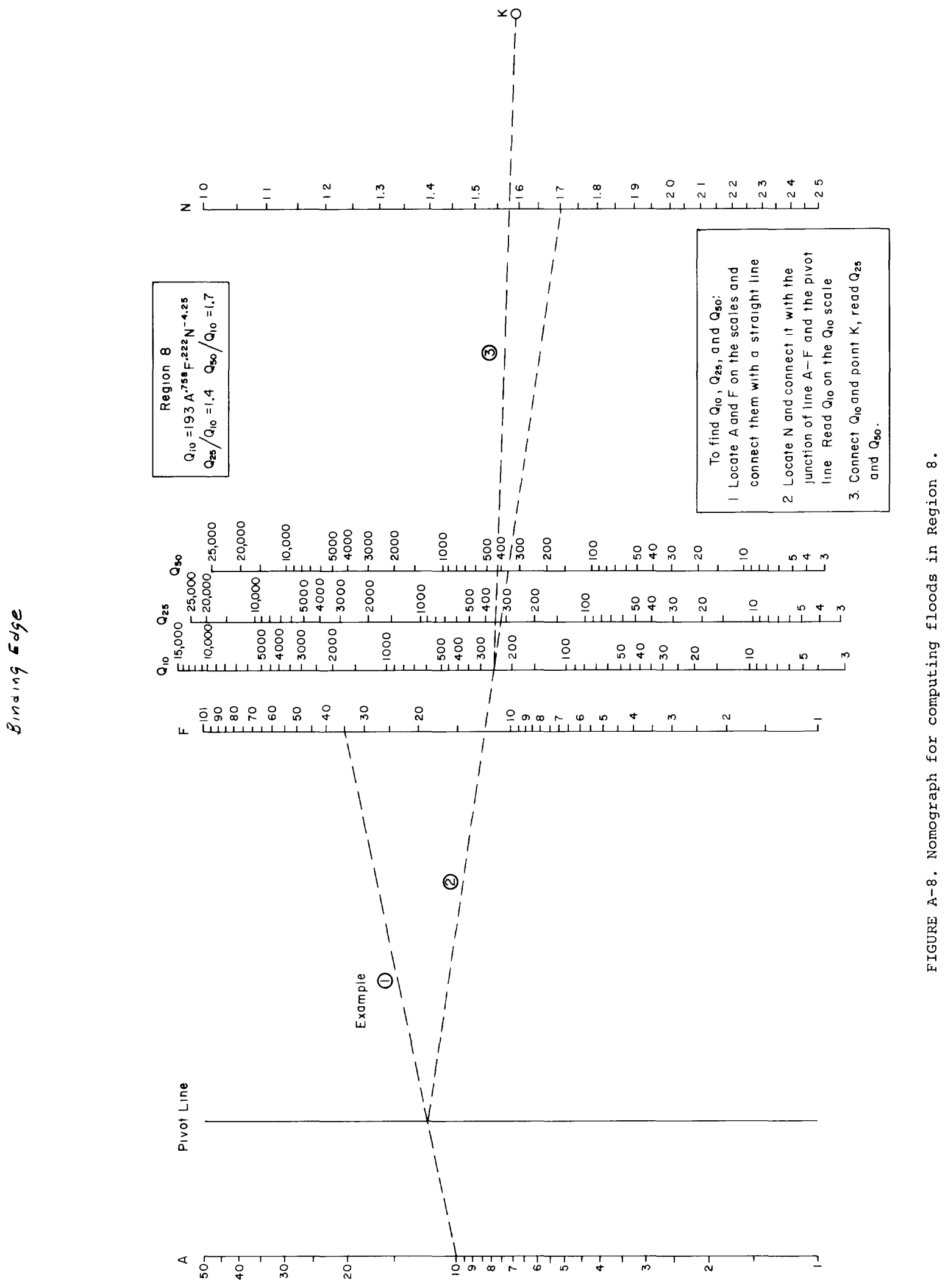





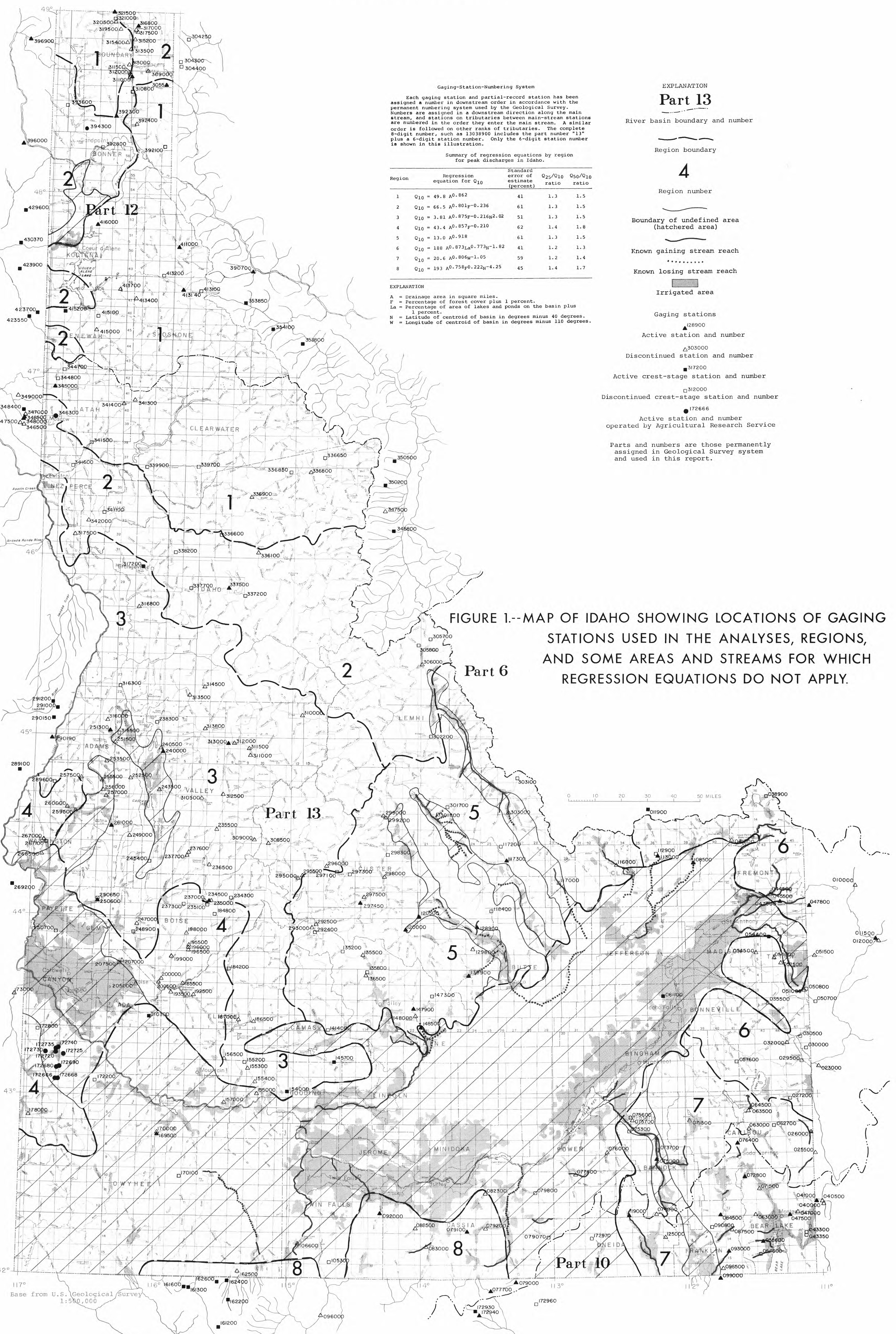



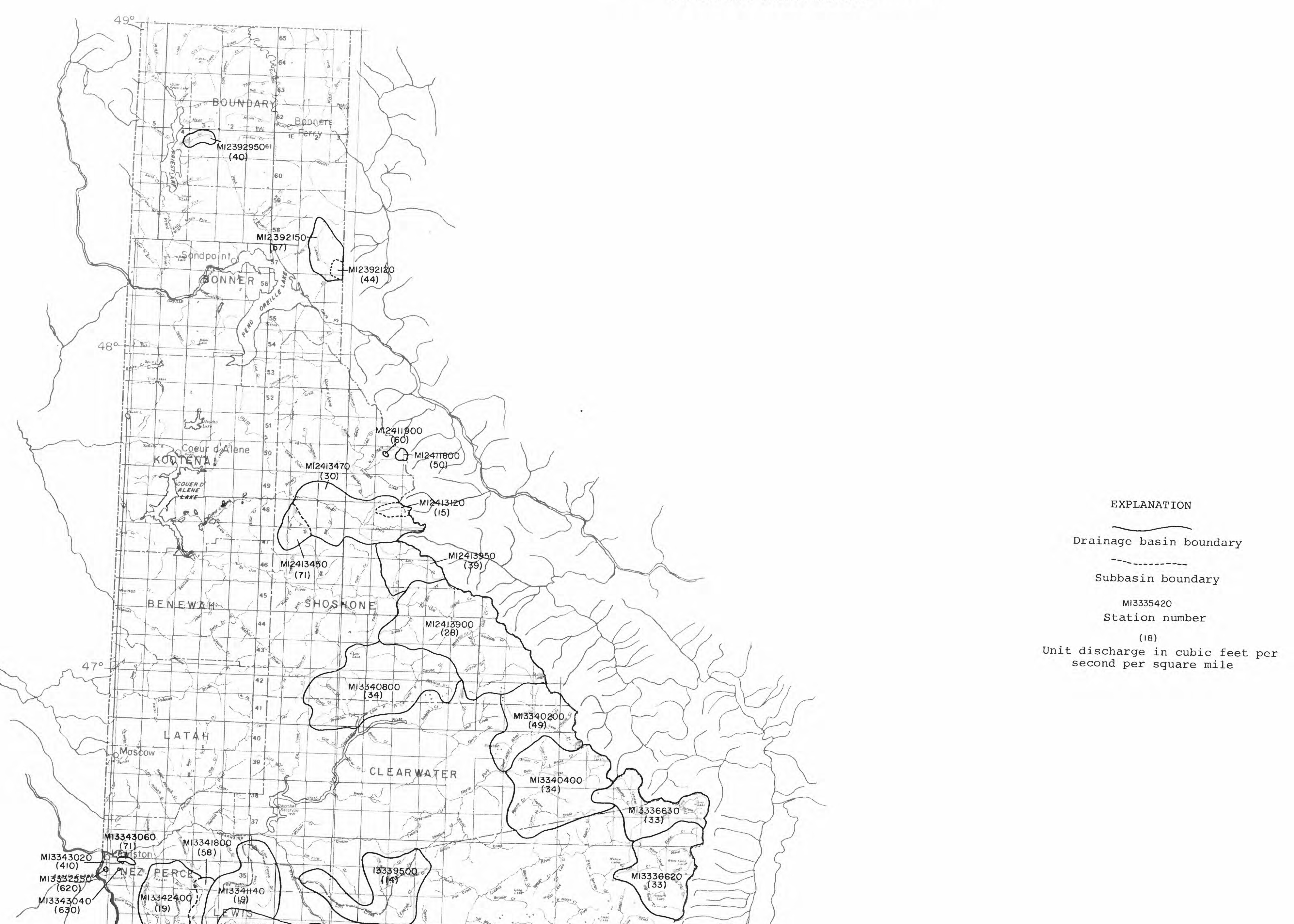

FIGURE 2.--MAP OF IDAHO SHOWING BASIN BOUNDARIES AND MAXIMUM KNOWN UNIT DISCHARGES AT MISCELLANEOUS SITES.

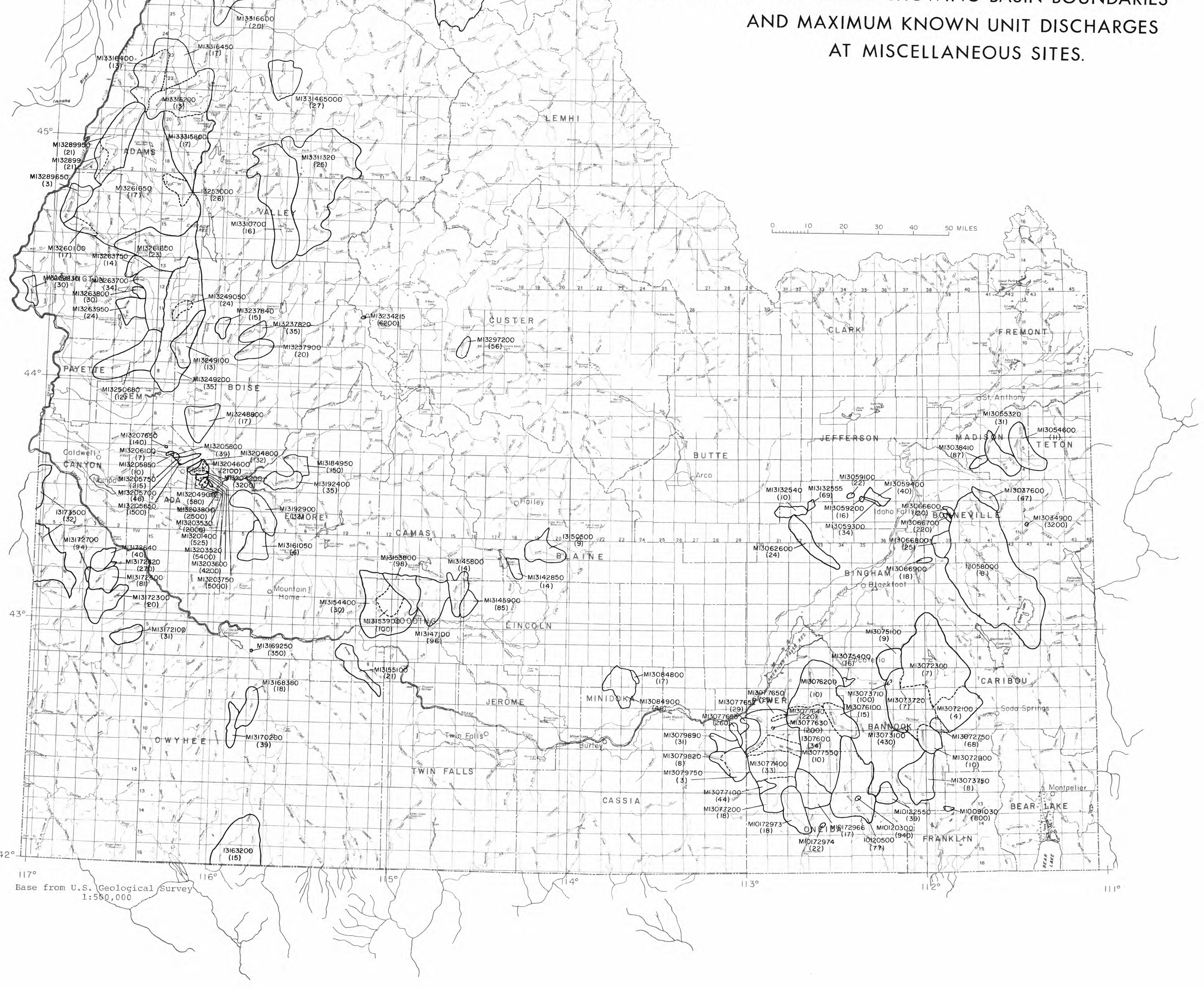




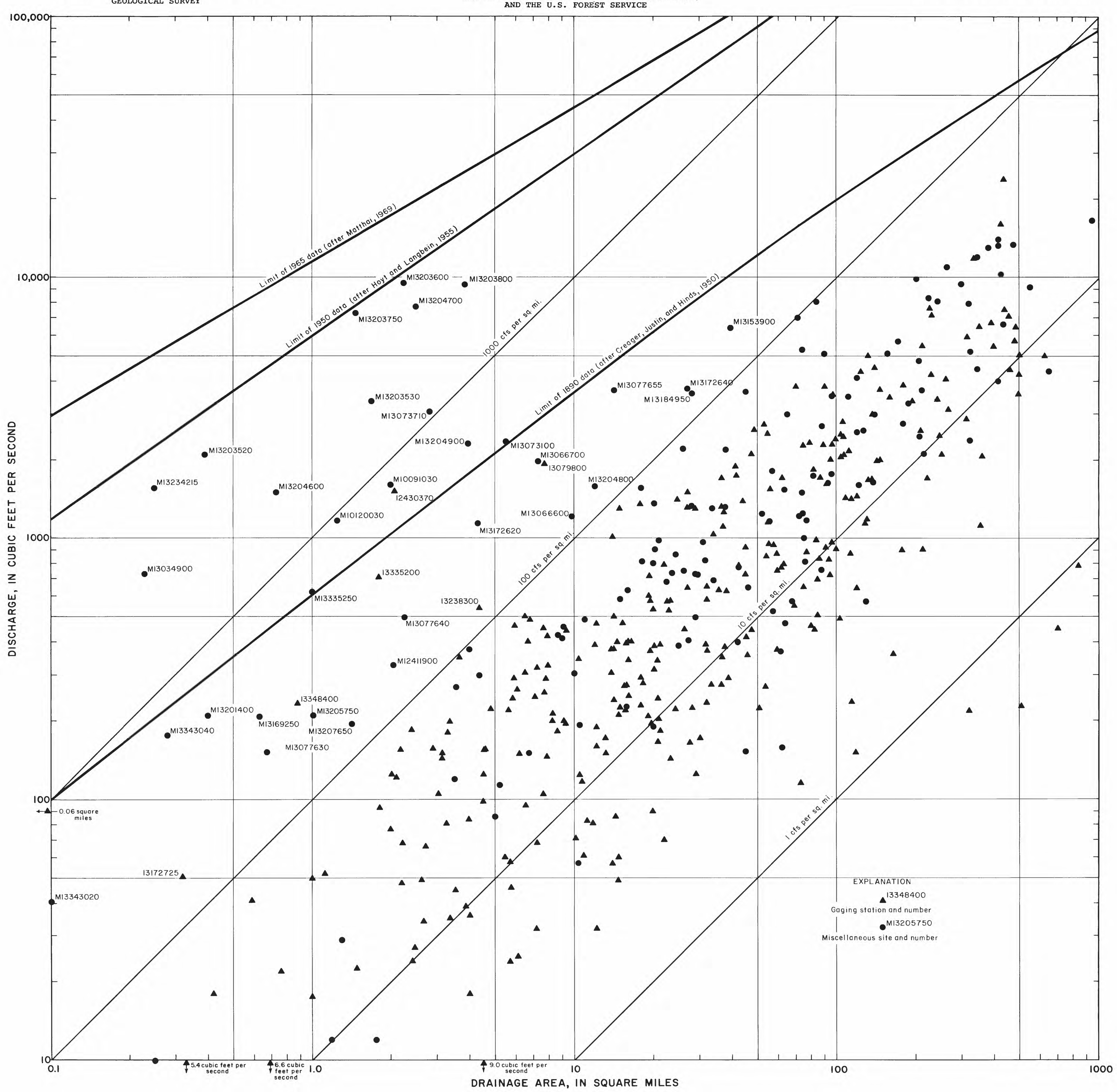

FIGURE 3.-- MAXIMUM DISCHARGES IN RELATION TO DRAINAGE AREA. 